
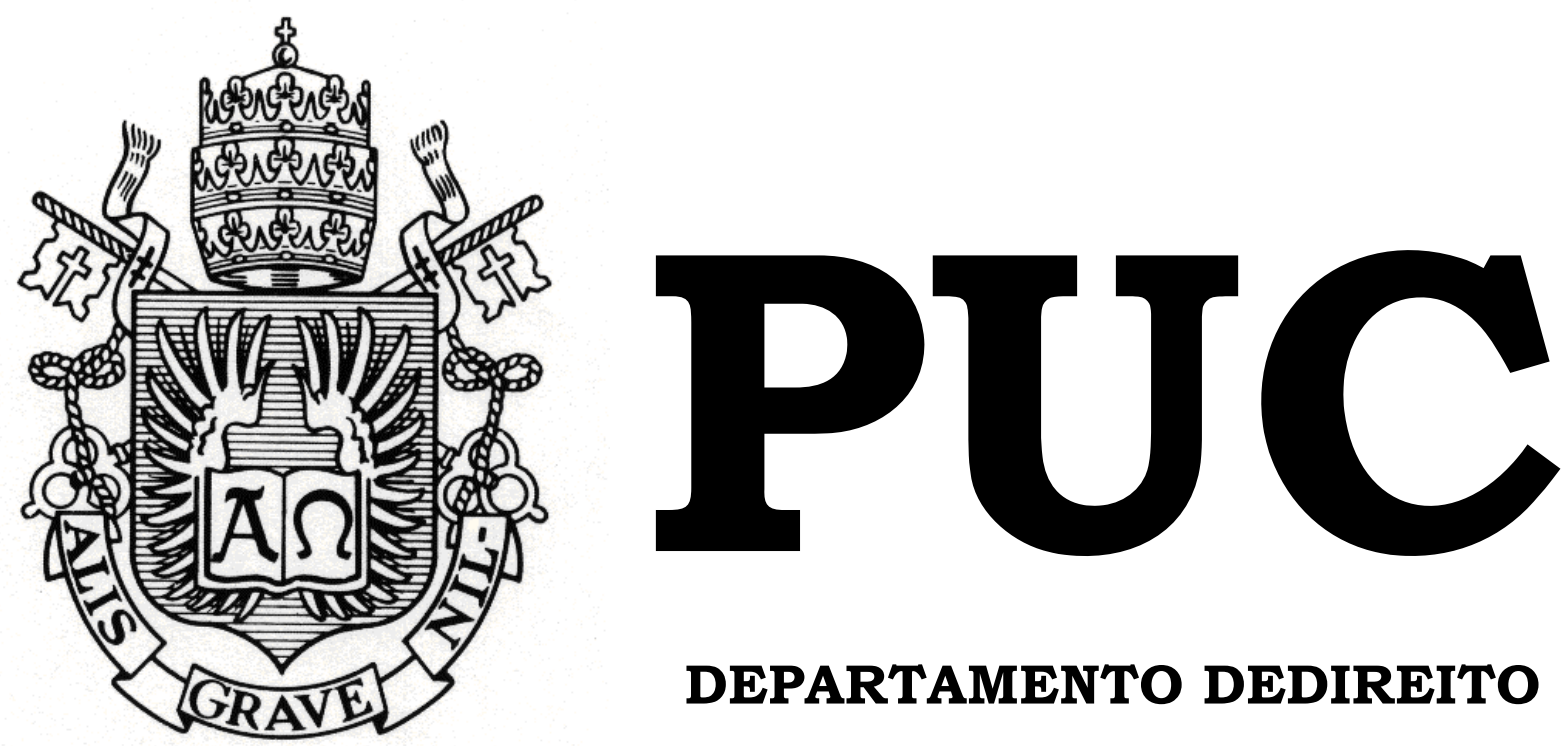

DEPARTAMENTO DEDIREITO

\title{
OFERTA PÚBLICA PARA AQUISIÇÃO DE CONTROLE
}

\author{
por
}

Pietro Bianchi

ORIENTADORA: NORMA PARENTE

2010.2

PONTIFÍCIA UNIVERSIDADE CATÓLICA DO RIO DE

$$
\text { JANEIRO }
$$

RUA MARQUÊS DE SÃO VICENTE, 225 - CEP 22453-900

$$
\text { RIO DE JANEIRO - BRASIL }
$$




\title{
OFERTA PÚBLICA PARA AQUISIÇÃO DE CONTROLE
}

\author{
por
}

\section{PIETRO BIANCHI}

Monografia apresentada ao Departamento de Direito da Pontificia Universidade Católica do Rio de Janeiro (PUC - Rio) para a obtenção do Título de Bacharel em Direito.

Orientadora: Norma Parente 


\section{Dedicatória}

Dedico o presente trabalho aos meus pais que sempre se esforçaram muito para me dar a melhor educação e transmitir bons valores. Aos meus falecidos avós, que me deram muito carinho e que hoje me fazem muita falta. 


\section{Agradecimentos}

Aos meus pais, Paolo e Regina, que me ensinaram a andar com as minhas próprias pernas, mas que sempre caminharam ao meu lado para me dar a ajuda necessária para que eu pudesse realizar os meus sonhos e superar minhas metas.

Aos meus saudosos avós, Vittorio, Carla, Adamir e Mariuccia, que nos durante a minha infância sempre me deram muito carinho e me proporcionaram muitas felicidades que jamais sairão da minha memória.

A meu padrasto e amigo Luciano, que nos últimos anos sempre me deu um grande apoio para os meus projetos.

Aos meus queridos amigos, pois sem eles a vida não teria a menor graça. Em especial, ao meu amigo Bernardo Monteiro por ter disponibilizado alguns livros da extensa biblioteca do seu falecido pai.

Aos meus atenciosos chefes da Gerência de Projetos Internacionais do Departamento Jurídico da Vale, em especial à Roberta que me proporcionou boa parte do material para esta monografia.

Finalmente, agradeço a professora orientadora, por dedicar parte do seu valioso tempo para me orientar e que sempre me deu importantíssimas sugestões através do seu vasto conhecimento em direito societário, além de ter aberto os meus olhos para este tema pouco estudado na doutrina brasileira. 


\section{Resumo}

O presente trabalho monográfico visa apresentar uma análise sobre o instituto da oferta pública para aquisição de controle de companhia aberta no ordenamento jurídico brasileiro. Esse instituto, que é regulado pelos artigos 257 ao 263 da Lei 6404/76 (Lei das Sociedades por Ações) e pela Instrução n³61 da CVM, tem por objetivo a aquisição do controle originário de companhia aberta através da oferta pública de aquisição de ações.

No primeiro capítulo, analisaremos além do instituto, as características das sociedades que possam ser alvo de uma oferta pública para aquisição do seu controle .

Nos demais capítulos, verificaremos: a legislação aplicável; algumas comparações pontuais com legislações de países com o mercado de capitais mais desenvolvido; as futuras alterações da Instrução CVM n 361 e, por fim, na conclusão com uma crítica à regulamentação brasileira.

\section{Palavras-Chave:}

Oferta Pública de Ações; Oferta Pública para Aquisição de Controle; Oferta Pública Voluntária; aquisição de controle; art. 257 da Lei 6404/76 (Lei das Sociedades Anônimas); Instrução CVM n 361. 


\section{Epígrafe}

"Tudo aprende o homem, quando não lhe falta coragem"

José de Alencar 


\section{Sumário}

\section{Introdução}

1.1. Características das companhias alvo da oferta pública para Aquisição de controle.

\section{A oferta pública para aquisição de controle seus requisitos e mecanismo.}

2.1 A exigência de instituição financeira intermediária.

2.2. Número mínimo de ações objeto da oferta.

2.3. Irrevogabilidade da oferta. Edital

2.4. Tipos de Oferta quanto a forma de liquidação financeira: moeda corrente, permuta, mista e alternativa.

2.4.1. Liquidação financeira através de permuta: formalidades e dificuldades.

2.5. Requisitos do instrumento de oferta.

2.6. Aceitação da oferta e o leilão.

2.7. Sigilo.

2.8. Aspecto Contratual.

\section{Oferta Pública Concorrente}

\section{Comentários à Minuta de Alteração da Instrução CVM n³61.}

4.1. Divulgação da oferta ao mercado: seus efeitos, sigilo e anúncio.

4.1.1 Anúncio.

4.2 Regras e restrições à negociação dos valores mobiliários de emissão da companhia alvo durante o período da oferta.

4.3. Manifestação do Conselho de Administração da companhia alvo sobre a oferta. 
4.4. Aquisição das ações remanescentes e aprovação da oferta parcial por mais da metade dos acionistas.

4.5. Procedimento especial

5. Conclusão

Referências bibliográficas 


\section{Abreviações}

Art. - Artigo

$\mathrm{N}^{\circ}$ - Número

Lei das S.A. - Lei ${ }^{\circ}$ 6.404 de 15.12.1976

Lei 9.457 - Lei n 9.457 de 05.05.1997

CVM - Comissão de Valores Mobiliários

Instrução CVM 361- Instrução N³61, de 05/03/2002

SEC - Securities Exchange Comission

Takeover Code - City Code on Takeovers and Mergers 


\section{Introdução}

O presente trabalho visa em um primeiro momento demonstrar as situações em que são possíveis a ocorrência da oferta pública para aquisição de controle de companhia aberta, passando, sobretudo, pela característica de concentração acionária das companhias brasileiras com capital aberto, o que justifica a escassez dessa forma de oferta. Em seguida, buscaremos apresentar o mecanismo desse tipo de oferta pública, desde o momento anterior à publicação do edital até a liquidação financeira, especificando a regulamentação que lhe é aplicada, bem como fazendo algumas comparaçóes pontuais desse instituto nos países onde ele é mais desenvolvido. Faremos, também, comentários à minuta que altera a Instrução CVM nº361 de 2002. Por fim, concluiremos esse estudo com uma análise crítica da regulamentação lacunosa e conflitante que temos no Brasil, bem como indicando as melhorias apresentadas pela minuta de alteração da Instrução CVM nº361.

Em poucas linhas, a oferta pública de aquisição de controle (takeover bid) é uma proposta pública irrevogável de compra de ações de uma determinada companhia aberta (target) feita por uma pessoa natural ou jurídica (bidder ou offeror). A oferta é destinada à pessoas indeterminadas que possuem a característica comum de serem proprietárias das ações objeto da oferta. Essa aquisição estará, necessariamente, condicionada à compra de um número de ações suficiente para assegurar o controle da companhia alvo. A quantidade de ações a serem compradas deverá estar especificado no edital de oferta.

Uma característica importante desse tipo de oferta é a indeterminação dos destinatários da oferta, bastando que esses sejam proprietários da mesma classe ou espécie de ações objeto da oferta. Essa é uma característica relevante pois, 
se os destinatários fossem todos facilmente identificados, seria mais simples realizar uma oferta através de um contato direto que, caso aceito, ensejaria a celebração de um simples contrato de compra e venda de ações entre as partes. Dessa forma, a oferta pública de aquisição de controle deverá ser dirigida ao público por meio de edital, conforme dispõe o artigo 4, inciso IX, da Instrução $\mathrm{CVM} \mathrm{n}^{\circ}$ 361, de 4 de março de 2002.

A Oferta Pública para Aquisição de Controle de uma companhia aberta é um evento raro e quase desconhecido na prática do mercado de capitais brasileiro, por outro lado essa é prática bem comum nos países com o mercado de capitais mais desenvolvido, onde, em regra geral, não há controle definido e as ações estão muito pulverizadas no mercado, como, por exemplo, nos Estados Unidos e nos países da Europa Ocidental.

Para fins históricos, a primeira oferta pública de aquisição de controle foi realizada em 1971, por iniciativa do Grupo Gerdau. Conforme relata Modesto Carvalhosa:

“A primeira operação desse gênero ocorreu em 15 de outubro de 1971, em Porto Alegre, por iniciativa do Grupo Gerdau.

Nesse dia, foi publicado um edital anunciando a constituição de uma companhia de capital autorizado denominada Macrosul S.A., tendo como principal acionista a holding do Grupo Gerdau, denominada Corpora, com capital de cem milhões de cruzeiros. Propunha essa mesma sociedade, ainda em fase anterior ao arquivamento dos atos constitutivos, adquirir todas as ações ordinárias do Sulbanco, ao preço de Cr\$ 4,00 (quatro cruzeiros) cada, sob condição de alcançar aceitações correspondentes ao número mínimo de 15.750 .00 ações, consideradas suficientes para dar ao ofertante o controle acionário da Sulbanco.

Propunha a Marcosul adquirir as ações dando como pagamento parte em dinheiro e parte em ações do capital dela própria.

Tratava-se de uma oferta agressiva e resultava de um dissídio entre os controladores de uma terceira companhia, a Bansulvest. Com efeito, o Sulbanco visado na oferta - e a Corpora eram controladores do Bancosulvest, em igualdade de condições cada um com $50 \%$ das ações votantes. Tendo em vista essa situação, não interessava à Corpora (Grupo Gerdau) a fusão que o Sulbanco pretendia efetuar com o 
Brasul-Comercial de São Paulo. Não dispondo de meios para obistruir a operação, a Corpora decidiu adquirir o controle do Sulbanco com o objetivo de impedi-la.

Não tendo obviamente o apoio dos administradores do Sulbanco e sendo o capital votante deste diluído por número muito grande de pequenos acionistas, decidiu o grupo Gerdau tentar a aquisição de controle através da oferta pública referida.

No dia seguinte à sua publicação, a diretoria do Sulbanco declarou desistir da fusão, desparecendo, portanto, o motivo da oferta que era o de manter o Bansulvest sob controle de capitais gaúchos. Seguiu-se a desistência da proposta evidentemente, muito antes do termino do prazo de 15 dias marcado para a validade da mesma." ${ }^{1}$

O que torna indispensável essa citação é o fato de que na época não existia qualquer regulamentação sobre ofertas públicas de aquisição de ações. Além disso, foi realizada uma oferta agressiva, ou seja, contrária aos interesses dos administradores da Sulbanco. Ainda, a forma de pagamento escolhida foi a forma mista, na qual a liquidação financeira se faz mediante pagamento em dinheiro e permuta de ações. Entretanto, como observado anteriormente, o Brasil não é um país onde este tipo de operação é comum.

Essa escassez de ofertas públicas para aquisição de controle no Brasil tem sua explicação na história de concentração acionária das companhias brasileiras $^{2}$, ou seja, a maioria das companhias abertas possui um controlador ou grupo de controle que detém mais da metade das ações com direito a voto. Como veremos mais adiante, esse tipo de companhia não poderá ser alvo dessa oferta.

As companhias abertas brasileiras possuem uma característica comum entre as demais sociedades de capital aberto em toda America Latina. Em geral elas são controladas por poderosas famílias tradicionais, por grandes

\footnotetext{
${ }^{1}$ CARVALHOSA, Modesto de Souza Barros. Oferta pública de aquisição de Ações, Rio de Janeiro, IBMEC, 1979. p. 115 e 116.

2 Neste sentido: "No Brasil tem sido raro os casos de aquisição de controle mediante oferta pública porque são raras as companhias abertas cujo controle é assegurado pela posse de ações representativas de menos de $50 \%$ do capital social com direito a voto. As transferências de controle de companhia
} 
conglomerados industriais ${ }^{3}$, multinacionais, fundos de pensão ou algumas, ainda, pelo Estado. Via de regra, esses controladores possuem o chamado controle majoritário, ou seja, possuem mais da metade do capital votante da sociedade. O White Paper on Corporate Governance in Latin America ${ }^{4}$ (Relatório Oficial sobre Governança Corporativa na America Latina), em seu Anexo C, traz uma interessante tabela com os tipos de controladores de empresas em alguns países da America Latina, como se vê abaixo:

\begin{tabular}{|c|c|c|c|c|c|c|}
\hline \multirow[b]{2}{*}{ País } & \multicolumn{4}{|c|}{ Tabela $3^{5}$} & \multirow[b]{2}{*}{$\begin{array}{l}\text { Número } \\
\text { de Grupos } \\
\text { (1) (1997) }\end{array}$} & \multirow[b]{2}{*}{$\begin{array}{c}\% \text { de } \\
\text { afiliação } \\
\text { Grupos } \\
\text { (2) (2002 }\end{array}$} \\
\hline & $\begin{array}{c}\text { Controle } \\
\text { Nacional- } \\
\text { Privado }\end{array}$ & $\begin{array}{c}\text { Controle } \\
\text { Estrangeiro }\end{array}$ & $\begin{array}{c}\text { Controle } \\
\text { do Estado }\end{array}$ & $\begin{array}{c}\text { Propriedade } \\
\text { Dispersa }\end{array}$ & & \\
\hline Argentina* & $38,6 \% *$ & $59,1 \% *$ & $2,3 \% *$ & $0 \% *$ & 11 & $93 \%$ \\
\hline Brasil** & $43 \% * *$ & $33 \% * *$ & $21 \% * *$ & $3 \% * *$ & 38 & $89 \%$ \\
\hline Chile & $69 \%$ & $30 \%$ & $0,8 \%$ & $0 \%$ & $50 * * *$ & $68 \%$ \\
\hline Colômbia & & & & & 7 & $50 \%$ \\
\hline México & & $18 \% * * * *$ & & & 14 & $72 \%$ \\
\hline Peru & & & & & 5 & $100 \%$ \\
\hline Média & & & & & 19,2 & $79 \%$ \\
\hline
\end{tabular}

aberta se realizam em geral mediante contratos de cessão de controle.”LAMY FILHO, Alfredo e PEDREIRA, José Luiz Bulhões, et al. Direito das Companhias, 1a ed., 2009, p 2032.

${ }^{3}$ De acordo com Fernando Lefort, em Ownership Structure and Corporate Governance in Latin America Contries - An Empirical Overview, 2003, Annex C do White Paper on Corporate Governance in Latin America, conglomerados industriais (conglomerates) significam, em tradução livre feita pelo Pinheiro Neto Advogados, "Um conglomerado é um grupo de empresas ligadas por meio de vínculos patrimoniais e controladas por famílias locais, um grupo de investidores atuando em conjunto ou, como observado mais frquentemente, por uma sociedade estrangeira. Geralmente, os conglomerados são controlados pelos acionistas majoritários em estruturas relativamente complexas que incluem o uso de pirâmides, participações cruzadas e Ações com ou sem direito a voto".

${ }^{4}$ White Paper on Corporate Governance in Latin America - Organization for Economic Co-operation and Development -OECD, 2003.

${ }^{5}(1)$ Khanna and Yafeh (2000) "Business Groups and Risk Sharing Around the World". Working Paper. Except Chile.

(2) For Argentina, Brazil, Colombia and Peru, data from 20-F ADR filings.

* Apreda (2000). 40 largest firms.

** Siffert, Nelson "Governança Corporativa: Padrões internacionais e evidências empíricas no Brasil nos anos 90". Working Paper.

****efort, Tarziján, Espinosa (2003) "Corporate Investment in Chile: Group Effect". Pontificia Universidad Católica de Chile. 
Atualmente no Brasil, as grandes empresas brasileiras listadas na bolsa possuem basicamente três origens: (i) surgiram de famílias poderosas, com controle familiar que passam de geração em geração; (ii) são subsidiárias de multinacionais que se instalaram no Brasil; ou (iii) foram criadas pelo Estado, algumas das quais foram privatizadas nos anos noventa. As grandes empresas brasileiras abriram o seu capital com o único intuito de se capitalizarem para poder expandir suas operações e poder concorrer no mercado globalizado.

Com as privatizações ocorridas durante a década de noventa, a presença do Estado no controle das grandes companhias abertas caiu fortemente, mas ainda assim há uma expressiva atuação do mesmo, detendo o controle de gigantes como a Petrobras, e até em empresas privadas como é o caso da Vale (nesse caso, o Estado possui influência indireta no grupo de controle (Valepar S.A.) através da Fundação Petrobras de Seguridade Social - Petros, Caixa de Previdência dos Funcionários do Banco do Brasil - Previ e BNDESPAR, além de possuir participação direta em ações preferenciais, ordinárias e golden shares com poder de veto em algumas questões estratégicas).

O relatório realizado pela Organização para Cooperação e Desenvolvimento Econômico - OCDE, em 2003, sobre governança corporativa na América Latina "White Paper on Corporate Governance in Latin America", trouxe um estudo sobre a concentração acionária das companhias abertas na América Latina. No Anexo C do referido relatório, Fernando Lefort ${ }^{6}$ reforça os argumentos apresentados acima de que as companhias latino americanas possuem alta concentração acionária e, com base na tabela abaixo elaborada pela ECONOMATICA ${ }^{7}$, o autor afirma,

\footnotetext{
${ }^{6}$ Fernando Lefort é professor na Faculdade de Economia da Pontifícia Universidade Católica do Chile e diretor do Centro de Governança Corporativa dessa faculdade e universidade.

${ }^{7}$ ECONOMATICA é um banco de dados de análise de investimentos que proporciona informações de Mercado e financeiras para empresas de capital aberto em alguns países da America Latina.
} 
referindo-se à empresas de capital aberto no Argentina, Brasil, Chile, Colômbia, México e Peru, que: “O maior acionista individual dessas sociedades detém, em média 53\%, do total das ações, e os cinco maiores acionistas somam cerca de $80 \%$ do total das ações”.

\begin{tabular}{|c|c|c|c|c|}
\hline \multirow[b]{2}{*}{ País } & \multicolumn{2}{|r|}{$\begin{array}{c}\text { Tabela } 2 \\
\text { Concetraçao de } \\
\text { Participação }\end{array}$} & & \\
\hline & $\begin{array}{l}\text { Amostra } \\
\text { (2002) }\end{array}$ & $\begin{array}{l}\% \text { do maior } \\
\text { acionista } \\
(2002)\end{array}$ & $\begin{array}{l}\text { \% dos } 3 \text { maiores } \\
\text { acionistas } \\
(2002)\end{array}$ & $\begin{array}{l}\% \text { dos } 5 \text { maiores } \\
\text { acionistas } \\
\text { (2002) }\end{array}$ \\
\hline Argentina** & 15 & $61 \%$ & $82 \%$ & $90 \%$ \\
\hline Brasil* & 459 & $51 \%$ & $65 \%$ & $67 \%$ \\
\hline Chile* & 260 & $55 \%$ & $74 \%$ & $80 \%$ \\
\hline Colômbia* & 74 & $44 \%$ & $65 \%$ & $73 \%$ \\
\hline México** & 27 & $52 \%$ & $73 \%$ & $81 \%$ \\
\hline Perú* & 175 & $57 \%$ & $78 \%$ & $82 \%$ \\
\hline Media & 168,3 & $53 \%$ & $73 \%$ & $79 \%$ \\
\hline
\end{tabular}

*Fonte: Economatica

**Fonte: Formulários 20-F American Deposit Receipt

Conforme extraímos desses dados, as companhias abertas brasileiras apresentam um controle altamente concentrado, ao contrário das companhias abertas americanas, que desde o início do século passado já possuíam várias formas de controle, como se pode observar através do estudo de Berle e Means que, em 1932, já listavam cinco tipos de controle.

A partir do final da presente década, o mercado de capitais brasileiro vem se transformando bastante, com muitas empresas abrindo o capital para captar recursos e tornando-se grandes players globais nos seus setores. Apesar da concentração acionária ter diminuído, com a entrada de muitos investidores pessoas físicas e principalmente de fundos estrangeiros (impulsionados pelas boas avaliações do Brasil pelas principais agências de risco), as companhias 
brasileiras ainda estão longe de possuírem uma dispersão acionárias parecida à das companhias americanas.

Isso não significa um atraso em relação aos outros países, já que é inegável que não temos um nível de presença de investidores individuais e institucionais como nos países mais desenvolvidos. Até nestes países ocorre concentração acionária, pois o todo poder tende a se concentrar ${ }^{8}$, hoje as grandes multinacionais buscam adquirir ou fundir-se com suas concorrentes para sobreviver no mercado competitivo, diminuindo seus custos com pessoal através de sinergias que fazem com que essas empresas reduzam seus custos operacionais e compartilhem boas praticas de governança corporativa.

Dito isto, passaremos agora a analisar quais os tipos de sociedades que podem ser alvos (target) de uma oferta pública de aquisição de controle.

\subsection{Características das companhias alvo da oferta pública.}

Conforme afirmado anteriormente, as sociedades anônimas de capital aberto que poderão ser alvo de uma aquisição de controle mediante uma oferta pública devem ser, necessariamente, companhias com o capital social pulverizado. Isto significa que nenhum acionista ou grupo de acionista pode

deter mais que 50\% das ações com direito a voto, ou seja, não há um controlador majoritário.

Não é o objetivo do presente trabalho, mas vale a pena fazer uma breve exposição sobre as formas de poder de controle. Segundo a famosa obra de Adolf Augustus Berle e Gardiner Means, The Modern Corporation and Private 
Property, existem cinco tipos de controle: (i) com participação acionária total (ou quase); (ii) majoritário; (iii) obtido mediante expediente legal; (iv) minoritário; e (v) gerencial.

Dessas cinco formas de controle, só nos interessam as últimas duas (iv e v), pois são as únicas companhias com uma estrutura acionária que possibilita que elas sejam um target de uma oferta para aquisição de controle. Chegamos a essa conclusão a partir da exclusão das outras formas de controle, tendo uma premissa em mente.

Como afirmado anteriormente, a oferta deve ser direcionada a pessoas indeterminadas que possuem a característica de serem proprietárias da mesma classe e espécie de ações objeto da oferta. Do contrário, bastaria o interessado buscar os acionistas definidos (devem ser poucos), negociar e celebrar um contrato de compra e venda de ações, o que seria muito menos oneroso, trabalhoso e arriscado do que fazer uma oferta pública para adquirir o controle. Com essa informação em mente, vamos partir para a exclusão das demais formas de controle.

O controle majoritário e o controle com quase a totalidade das ações com direito a voto possuem a mesma razão para serem excluídas. Uma companhia que possui este tipo de controlador, não poderá ser alvo de oferta pública para aquisição de controle. Isso se dá pelo simples fato de existir um acionista (ou grupo de acionistas) com mais da metade das ações com direito a voto e caso uma oferta fosse feita, ela seria dirigida apenas a uma pessoa (ou grupo de pessoas com acordo de voto), sendo assim, a oferta não seria dirigida ao público (pessoas indeterminadas).

\footnotetext{
8 Neste sentido: "De mais a mais, todo poder tende à concentração, seja qual for a sociedade em que se exerça” COMPARATO, Fabio Konder e SALOMÃO FILHO, Calixto. O poder de controle na
} 
Especialmente nessas companhias com este tipo de controle, ocorre a alienação de controle, que é pactuada entre um comprador interessado em adquirir o controle, e o vendedor que possui o controle majoritário (50\% das ações mais uma). Nesse caso, sendo uma companhia aberta, aplica-se o 254-A da LSA (alienação de poder de controle), o que acaba acarretando outro tipo de oferta pública. Essa tem o objetivo de estender a possibilidade para que os minoritários (acionistas não controladores com direito a voto) possam vender as suas respectivas participações por um preço não inferior a $80 \%$ do valor pago (às ações de mesma classe e espécie) pelas ações do acionista controlador.

Essa forma de aquisição, e consequentemente de OPA de alienação de controle, é muito mais comum no Brasil, tendo em vista a forte concentração acionária das companhias listadas. Ela também acaba apresentando menos riscos ao adquirente, uma vez que ele poderá fazer uma due diligence (auditoria) na empresa que ele deseja comprar e analisar cuidadosamente os ativos e as contingências da empresa para que ele possa avaliar melhor o negócio, o que não ocorre no caso de um oferta pública para aquisição de controle, como veremos melhor mais adiante.

A outra forma listada por Berle e Means é o controle obtido mediante expediente legal. Segundo esses autores, existem três formas de controle mediante expediente legal: (i) através do controle piramidal ou em cadeia em grupo societário; (ii) por meio de existência de ações sem direito a voto ou com voto limitado; e (iii) por meio de voting trust. De acordo com Fabio Konder Comparato ${ }^{9}$, somente este último (iii) poderia se diferenciar das 
demais espécies de controle, contudo o trustee não pode ser assimilado a um acionista, pois ele exerce o controle sem a propriedade, consequentemente, ele não poderá dispor da ação.

Nos restaram agora o controle minoritário e o controle gerencial, que são as formas de controle de companhias abertas que poderão ser alvo de uma oferta pública de aquisição de ações. O surgimento do controle minoritário, segundo Fabio Konder Comparato, é devido ao "vigoroso desenvolvimento do mercado de capitais e à grande dispersão acionária, verificada nas macrocompanhias de capital fechado”. ${ }^{10}$ Em poucas palavras, o controlador minoritário é aquele de "usa efetivamente seu poder para dirigir as atividades sociais e orientar o funcionamento dos órgãos da companhia”, conforme a alínea 'b' do artigo 116 da LSA. Entretanto, esse controlador (ou controladores, mediante acordo de acionistas) tem esse poder detendo menos da metade das ações com direito a voto da companhia. Isso é possível, devido a dois fatores: (i) sua participação minoritária, porém relevante que o faz preponderar nas assembleias gerais e conseguir eleger o maior número de administradores e; (ii) o capital da companhia ser de tal forma pulverizado que não existe outro acionista que possa vencê-lo nas votações das assembleias gerais.

Já o controle gerencial, apresenta a mesma característica do controle minoritário, a dispersão acionária. Todavia, no controle gerencial, a dispersão é tão acentuada que nenhum acionista prepondera nas assembleias gerais de forma contínua. Dessa forma, principalmente nos Estados Unidos e na Inglaterra, algumas empresas passaram a ser bem administradas por seus executivos, e esses passaram a se perpetuar nos cargos de administração, pois

10 Idib. p. 239. 
obtinham bons resultados e, em troca, os acionistas passaram a confiar na sua $\operatorname{administração~}^{11}$.

Analisadas brevemente as formas de controle que se aplicam ao instituto tema deste trabalho, ou seja, o controle minoritário e o controle gerencial, pode-se concluir que elas possuem as condições que possibilitam o bidder obter sucesso na sua oferta, pois se uma quantidade de acionistas com direito a voto suficiente para garantir o controle resolverem vender sua participação, o ofertante será capaz de conquistar o controle da companhia target.

Após essa introdução ao tema que serviu de referência e base para se poder entender e dar prosseguimento ao instituto da oferta pública para aquisição de controle, passar-se-á agora a sua forma, seus requisitos e mecanismo.

\footnotetext{
11 Alguns destes administradores, vieram a comprar até participações consideráveis na empresa de forma a garantir a perpetuação no cargo, como no caso de Jack Welch na General Eletric.
} 


\section{Oferta pública para aquisição de controle, os seus requisitos e mecanismos.}

\subsection{A exigência de Instituição Financeira.}

A oferta pública de aquisição de controle de companhia aberta é regulada pelos artigos 257 a 261 da LSA e pelo artigo 32 da Instrução nº 361 da CVM. Essa espécie de oferta tem por objeto a aquisição, por parte de um acionista ou de um terceiro interessado, de ações de uma empresa alvo em uma quantidade suficiente para lhe garantir o controle.

Após a publicação do edital contendo todas as especificações da oferta dirigida aos acionistas da empresa, esses terão um prazo para avaliar se possuem ou não interesse em alienar as suas ações ao ofertante. Caso, durante este prazo, o ofertante consiga a quantidade de aceitações indicada no edital (quantidade essa que deverá garantir-lhe o controle), a oferta será bem sucedida.

Essa oferta somente poderá ser efetuada mediante a contratação pelo ofertante de uma instituição financeira que garanta o cumprimento das obrigações assumidas no edital, conforme regula o caput do artigo 257. A Instrução $n^{0} 361$ da CVM, em seu art. $7^{\circ}$, especifica ainda mais a exigência, requerendo que seja uma instituição financeira com carteira de investimentos ou uma sociedade corretora ou distribuidora de títulos e valores mobiliários. A instituição financeira intermediária deverá garantir a liquidação financeira da oferta pública e o pagamento do preço de compra.

O papel da instituição financeira é importantíssimo no procedimento da oferta pública de aquisição de controle, ela deverá auxiliar o ofertante em todas 
as fases da oferta, exigindo o cumprimento, por parte do ofertante, de todas as formalidades estabelecidas na lei, devendo, inclusive, interromper a prestação de seus serviços caso o ofertante se recuse a cumprir tais formalidades, sob pena de permanecer co-responsável ${ }^{12}$ pelos atos e omissões ilegais, conforme redação do $\S 3^{\circ}$ do $\operatorname{artigo~}^{\circ}$ da Instrução CVM n 361.

A instituição financeira deverá ainda, conforme exige o $\S 2^{\circ}$ do artigo $7^{\circ}$ da Instrução CVM n³61, assegurar que todas as informações prestadas pelo ofertante sejam verdadeiras. Caberá à instituição intermediária, também, verificar a suficiência e a qualidade das informações fornecidas ao mercado durante todo o procedimento da oferta, inclusive sobre as informações presentes no edital, bem como pelo laudo de avaliação das ações da companhia alvo. A instituição financeira será responsável pelas omissões e informações falsas que venham a ser disponibilizadas.

Ainda de acordo com o mesmo artigo da referida Instrução da CVM, mais especificamente em seu $\S 6^{\circ}$, impõe-se a proibição da instituição intermediária negociar os valores mobiliários objetos da oferta. O douto Professor Carlos Augusto da Silveira Lobo estende essa limitação aos controladores e às partes relacionadas da instituição financeira ${ }^{13}$, pois entende que o referido parágrafo está se relacionando com o $\S 5^{\circ}$, que requer que essas pessoas apresentem declaração da quantidade de ações de emissão da companhia objeto de que sejam titulares, ou estejam sob sua administração.

\footnotetext{
${ }^{12}$ O entendimento do professor Carlos Augusto da Silveira Lobo é de que a instituição intermediária é co-obrigada com o ofertante: "Trata-se de co-obrigação e não de obrigação subsidiária, pois a instituição financeira subscreve o instrumento da oferta em conjunto com o ofertante”. LAMY FILHO, Alfredo e PEDREIRA, José Luiz Bulhões, et al. Op. Cit., p 2038

13 "A instituição intermediária, seu controlador e pessoas a ela vinculadas ficarão impedidos de negociar com os valores mobiliários objeto da oferta e deverão apresentar declaração da quantidade de valores mobiliários objeto da oferta de que sejam titulares, ou que estejam sob sua administração discricionária.” LAMY FILHO, Alfredo e PEDREIRA, José Luiz Bulhões, et al. Op. Cit., p 2037
} 
Deve-se tomar a devida atenção com a redação do $\S 4^{\circ}$ do artigo referido, pois essa pode ensejar incerteza em relação à exigência da instituição intermediária (financeira) garantir a liquidação financeira da oferta pública de aquisição de controle. A redação desse parágrafo nos inclina a interpretar que apenas existe tal exigência no caso do $\S 2^{\circ}$, art. 10 da referida Instrução da CVM, em que o ofertante tendo adquirido mais de 2/3 das ações de uma mesma espécie e classe em circulação, fica obrigado a adquirir as ações remanescentes.

Entretanto, esse artigo não se aplica apenas nessa hipótese restrita, conforme ensina Carlos Augusto da Silveira Lobo, a instituição financeira deverá garantir a liquidação financeira da oferta pública:

\begin{abstract}
“Como a Instrução CVM n 361 pretende regular exaustivamente todas as modalidades de oferta pública para aquisição de ações (“OPA”), inclusive as destinadas à aquisição de controle de companhia aberta, a omissão pode induzir ao erro de que a garantia da instituição financeira somente é exigível nos casos de aquisição obrigatória de ações remanescentes. Não é assim, entretanto o $\S 4^{\circ}$ do artigo $7^{\circ}$ da Instrução CVM n ${ }^{\circ} 361$ deve ser entendido como esclarecendo que a garantia da instituição financeira também é exigível nos casos nele referidos. É indubitável que a instituição financeira intermediária obriga-se solidariamente com o ofertante pelo cumprimento de todas as obrigações previstas no instrumento de oferta pública para aquisição de controle de companhia aberta, inclusive e muito especialmente pela liquidação e pagamento de todas as operações consumadas pelas aceitações”.
\end{abstract}

Nesse sentido é o entendimento do mercado, como se pôde observar no Edital de Oferta Pública Voluntária para Aquisição de Ações Ordinárias de Emissão da Paranapanema, em que a instituição intermediária Banco Bradesco BBI S.A. garantia a liquidação financeira da oferta "nos termos da regulamentação em vigor” ${ }^{\text {14 }}$, bem como na Oferta Pública para Aquisição de Controle da GVT (Holding) S.A. em que o Banco Santander (Brasil) S.A. foi

\footnotetext{
${ }^{14}$ Item 3.4 do referido Edital "Garantia de Liquidação Financeira. Nos termos da legislação em vigor, a Instituição Inermediária garantirá a liquidação financeira da Oferta”. Edital de Oferta Pública Voluntária para Aquisição de Ações Ordinárias de Emissão da Paranapanema. Publicado no Diário
} 
garantidor da liquidação financeira da oferta, conforme disposto no item 4.3 do Edital $^{15}$.

\subsection{Número mínimo de ações objeto da oferta.}

A redação do parágrafo $2^{\circ}$ do artigo 257 da Lei das Sociedades por Ações define que a oferta "deverá ter por objeto ações com direito a voto em número suficiente para assegurar o controle da companhia...”, nesse mesmo sentido, o inciso III do artigo 32 da Instrução CVM n 361 traz a mesma exigência formulada na LSA:

“III - A OPA deverá ter por objeto, pelo menos, uma quantidade de ações capazes de, somadas às do ofertante, de pessoas a ele vinculadas, e que com ele atuem em conjunto, assegurar o controle de companhia aberta.”

O texto desses dispositivos legais é claro ao afirmar que o número de ações objeto da oferta deverá dar ao ofertante uma posição que lhe assegure o controle da companhia alvo. Contudo, nenhum destes dispositivos normativos foi específico em afirmar que o número de ações que assegure o controle da companhia deva somar um mínimo de 50\% mais uma ação das ações com direito a voto da companhia, ou seja, controle majoritário.

Essa falta de precisão normativa pode acabar criando uma insegurança do intérprete da norma. Caberá analisarmos agora se a oferta pública prevista

Oficial do Estado do Rio de Janeiro, Ano XXXVI - No 139 - Parte V - Rio de Janeiro, terça-feira - 3 de agosto de 2010.

15 Item "4.3. Garantia de liquidação financeira. A instituição intermediária garantirá a liquidação financeira do leilão, exceto no que se refere a uma eventual oferta concorrente.” Republicação do Edital de Oferta Pública Voluntária de aquisição de Ações Ordinárias de Emissão da GVT (Holding) S.A.. Disponível 
no artigo 257 da LSA permite a formulação de uma oferta que tenha por objeto menos de $50 \%$ do capital com direito a voto.

Já se discutia, em 1979, se a oferta pública de aquisição de controle de companhia aberta poderia ter por objeto ações em um montante inferior aos $50 \%$ do capital votante da companhia alvo. ${ }^{16}$ Modesto Carvalhosa, em sua tese de doutorado publicada no referido ano, já sustentava que não seriam necessários os 50\% mais uma ação do total de ações com direito a voto para a aquisição de controle, como podemos observar abaixo, levando em consideração a legislação em vigor na época do referido trabalho:

"Evidentemente que se o controle é exercido por acionistas que possuem a maioria absoluta dos votos do capital social (item III da Resolução n ${ }^{0}$ 401, de 1976, do Branco Central do Brasil), o montante deve corresponder a 50\% mais uma dessas ações. Se, no entanto, o controle for minoritário (item IV da Resolução $n^{0} 401$, de 1976, do Banco Central do Brasil), o montante das ações objeto da oferta deve corresponder ao percentual necessário ao seu exercício.”

Como vimos na introdução do presente trabalho monográfico, o artigo 116 da LSA contempla a existência do controle minoritário, dessa forma um ofertante poderia adquirir o controle "de fato" de uma empresa, mesmo que ele adquirisse menos de $50 \%$ das ações com direito a voto ${ }^{17}$, desde que elegesse a maioria dos administradores, predominasse nas deliberações das Assembleias

\footnotetext{
16 "Nesta última hipótese, volta à baila a questão de oferta de aquisição de bloco de ações votantes. É, com efeito, impossível, a priori, se uma oferta voluntária de aquisição de um percentual minoritário de ações visa simplesmente uma participação substancial na companhia ou seu controle, mediato ou imediato. Assim sendo, não se pode deixar de aplicar às ofertas de aquisição de blocos de ações a disciplina das ofertas públicas de aquisição de controle.” CARVALHOSA, Modesto de Souza Barros. Op. Cit., 1979. p. 168.

${ }^{17}$ Conforme vemos na lição de Nelson Eizirik, "Note-se que, quanto à sua finalidade, as OPAs em questão dividem-se em duas espécies: (a) para aquisição de controle acionário, no caso em que o ofertante ainda não é acionistas da companhia alvo, ou não dispõe do montante necessário de ações que lhe assegurem o controle (art. 257 caput); (b) para reforço do controle acionário, na hipótese em que o ofertante já é titular de ações que lhe assegurem o controle acionário, mas deseja passar a deter ações representativas de mais de 50\% (cinqüenta por cento) do capital votante, consolidando seu poder de controle (artigo 257, § $3^{\circ}$ ). EIZIRIK, Nelson. et. al., Mercado de Capitais Regime Jurídico. Rio de Janeiro. Renovar. 2008.
} 
Gerais e usasse o seu poder para efetivamente dirigir as atividades sociais e orientar o funcionamento dos órgãos da companhia. ${ }^{18}$

Sendo assim, como a lei não define um número exato, não cabe ao intérprete do direito definir limitações mais amplas do que foi a intenção do legislador. ${ }^{19}$ Como os citados dispositivos legais se referem apenas à quantidade de ações suficientes que assegurem o controle, deverá se verificar caso a caso as ações em circulação e a concentração acionária de cada companhia alvo de uma oferta pública de aquisição de controle para que seja observado o número mínimo de ações que possa assegurar um controle estável ${ }^{20}$ para o adquirente.

Neste sentido, ensina Carlos Augusto da Silveira Lobo ${ }^{21}$ :

“A oferta deverá ter por objeto ações suficientes para assegurar o controle da companhia. Assim, se o ofertante já for titular de uma certa quantidade de ações com direito a voto, a oferta poderá ter por objeto a quantidade necessária para completar o bloco de controle. Note-se que o bloco de controle, que se pretende formar com a oferta, não será necessariamente constituído de ações representando mais de $50 \%$ do capital votante, tudo dependendo da dispersão das ações em circulação, mas será necessariamente maior do que o bloco de controle existente.”

${ }^{18}$ Neste sentido: "Muito discutida é a existência no referido artigo de dois requisitos par a qualificação do controle: em primeiro lugar, a existência de direitos de sócios que assegurem, de modo permanente, a maioria de votos na Assembleia Geral. Em segundo lugar, o uso efetivo do poder para dirigir as atividades sociais. Apesar de o primeiro requisito aparentemente indicar no sentido da exigência de controle majoritário, o segundo claramente é aplicável só a casos de controle minoritário. Em caso de controle majoritário é irrelevante o uso efetivo do poder: o acionista terá o status de controlador e as responsabilidades dele decorrentes, seja por ação ou omissão" COMPARATO, Fabio Konder; SALOMÃO FILHO, Calixto Op. Cit. p. 69.

19 "o legislador optou por não exigir a propriedade de percentual mínimo de ações votantes para caracterizar a figura do acionista controlador. Assim, deve ser examinada cada situação particular para que possa ser detectado quem é o titular do controle acionário" EIZIRIK, Nelson. Temas de Direito Societário, Rio de Janeiro: Renovar, 2005, p. 233

20 Controle minoritário instável seria aquele que na hipótese de uma companhia possuir dois maiores acionistas com participação semelhante e que nenhum deles consiga predominar por muitas assembleias consecutivas, ou seja, o controle fica variando de um acionista para o outro. No sentido oposto, o controle minoritário estável seria aquele que o acionista detenha uma concentração acionária suficiente para deliberar em todas as assembleias, mas que mesmo assim não possui ainda o controle majoritário, ou seja aquele com mais de 50\% mais uma ação do capital votante. 
O $\S 3^{0^{22}}$ do artigo 257 da LSA regula o caso de o ofertante já ser possuidor de ações com direito a voto de emissão da companhia alvo. Esse dispositivo afirma que esse acionista poderá realizar oferta pública para que possa completar o controle. Essa terminologia pode causar confusão aos interpretes da lei, como foi no caso do ilustre Doutor Nelson Eizirik. ${ }^{23}$ Realmente a lei não esclarece se há um controle minoritário por parte do ofertante e este deseja "completar o controle” adquirindo ações suficientes para alcançar a posição de acionista com maioria absoluta das ações com direito a voto, ou se a lei se refere a qualquer acionista, mesmo com participação ínfima, que deseja adquirir o controle (majoritário ou minoritário) da companhia. Conforme o entendimento de Modesto Carvalhosa, "na dúvida, devemos aceitar as duas hipóteses”24. Além disso, "não há piso, a partir do qual a lei exige a oferta pública para completar o controle”25.

Contudo, devemos atentar para o risco que pode envolver uma aquisição de controle que seja inferior a 50\% mais uma ação das ações com direito a voto. O ofertante poderá adquirir o controle da companhia através da sua oferta, mas não poderá garantir no futuro a manutenção da sua posição de controlador da companhia, caso adquira um controle minoritário.

Temos, v.g., a hipótese em que um ofertante se obriga, através do edital, em adquirir um mínimo de 30\% e um máximo de $40 \%$ do capital votante, considerando que no momento precedente da oferta não existia nenhum

\footnotetext{
${ }^{21}$ LAMY Filho, Alfredo e PEDREIRA, José Luiz Bulhões, et al. Op. Cit., p 2038.

22 "§3 - Se o ofertante já for titular de ações votantes do capital da companhia, a oferta poderá ter por objeto o número de ações necessário para completar o controle, mas o ofertante deverá fazer prova, perante a Comissão de Valores Mobiliários, das ações de sua propriedade.” EIZIRIK, Nelson. et. al., Op. Cit. Rio de Janeiro. Renovar. 2008.

${ }^{23}$ “.... (b) para reforço do controle acionário, na hipótese em que o ofertante já é titular de ações que lhe assegurem o controle acionário, mas deseja passar a deter ações representativas de mais de 50\% (cinqüenta por cento) do capital votante, consolidando seu poder de controle (artigo 257, § $3^{\circ}$ ).”

${ }^{24}$ CARVAlHOSA, Modesto de Souza Barros. Op. Cit. p.170.

${ }^{25}$ CARVALHOSA, Modesto de Souza Barros. Op. Cit. p.170.
} 
acionista ou grupo de acionistas que alcançasse este percentual. Concretizada a aquisição, poucos dias depois, a mesma companhia é alvo de uma nova oferta pública para aquisição de controle e o novo ofertante consegue adquirir 50\% mais uma ação do total das ações com direito a voto. Neste caso, o primeiro adquirente não irá conseguir exercer a sua posição de controlador e nem assegurar o controle que havia adquirido.

Podemos observar esse receio dos ofertantes nos recentes casos de oferta pública de aquisição de controle que acontecerem no Brasil. A GVT (Holding) S.A. e Parnapanema S.A. foram alvo, respectivamente, da Telefonica Telecomunicações de São Paulo S.A ${ }^{26}$. e Vale S.A.. Nos editais de oferta, o número mínimo de ações a serem adquiridas pelos ofertantes foi de 51\% de emissão da $\mathrm{GVT}^{27}$ e 50\% mais uma ação das ações de emissão da Paranapanema $^{28}$. Mesmo em países em que as empresas listadas apresentam um capital mais pulverizado, esta prática de adquirir, pelo menos, 50\% mais uma ação das ações com direito de voto é comum, como foi no caso da tentativa de aquisição de controle pela BHP Billiton Plc da Potash Corporation of Saskatchewan INC. ${ }^{29}$

A respeito da matéria, o Takeover Code, que é a regulamentação corporativa inglesa, apesar de considerar controle quem detém 30\% (ou até

\footnotetext{
${ }^{26}$ Neste acaso a oferta realizada pela Telefônica era uma oferta concorrente à efetuada pela Vivendi em 8 de setembro de 2009,

${ }^{27}$ Item 1.4 da Republicação do Edital de Oferta Pública Voluntária de aquisição de Ações Ordinárias de Emissão da GVT (Holding) S.A.. Disponível em http://www15.telefonica.com.br/investidores/sp/download/edital_OPA_novo_preco_051109.pdf.

Acesso em18 de novembro de 2010. Neste acaso a oferta realizada pela Telefônica era uma oferta concorrente à efetuada pela Vivendi em 8 de setembro de 2009,

${ }^{28}$ Item 1.4 do Edital de Oferta Pública Voluntária para Aquisição de Ações Ordinárias de Emissão da Paranapanema. Publicado no Diário Oficial do Estado do Rio de Janeiro, Ano XXXVI - No 139 Parte V - Rio de Janeiro, terça-feira - 3 de agosto de 2010.

29 "The BHP Offer is subject to a number of conditions, including that more than $50 \%$ of the Common Shares, on fully-diluted basis, are tendered to the BHP Offer.” PotashCorp Directors' Circular Resolution, August 23, $2010 . \quad$ p.1. Disponível em:
} 
menos) das ações com direito a voto de uma companhia aberta $^{30}$, não especifica o montante mínimo de ações que a oferta deve ter por objeto, Entretanto, o próprio Takeover Code, na sua RULE 10, determina que o ofertante deve obter aceitações correspondentes a mais de 50\% das ações votantes, a fim de que possa declarar a sua proposta incondicional. ${ }^{3132}$

\subsection{Irrevogabilidade da Oferta.}

Conforme o disposto no $\S 2^{\circ}$ do art. 257 da LSA a Oferta Pública de Aquisição de Controle é uma oferta irrevogável ${ }^{33}$, ou seja, o ofertante não poderá desistir de sua oferta após ela ter sido dirigida aos acionistas da companhia alvo através da publicação do edital. A irrevogabilidade também se estende à oferta concorrente do art. 262 da LSA ${ }^{34}$.

Contudo, o art. $5^{\circ}$ da Instrução CVM 361/02 apresenta uma disposição conflitante com a redação do $\S 2^{\circ}$ do art. 257 da LSA. Ele prevê que a CVM poderá autorizar a modificação ou revogação de ofertas sujeitas a registro

http://www.potashcorp.com/media/POT_PotashCorp_Directors_Circular.pdf. Acesso realizado em 25 de setembro de 2010.

30 O Takeover Code define controle como:“Control means an interest, or interests, in shares carrying in aggregate $30 \%$ or more of the voting rights (as defined below) of a company, irrespective of whether such interest or interests give de facto control.” The City Code On Takeover and Mergers, $9^{\text {th }}$ edition, March 30, 2009. Disponível na internet: http://www.thetakeoverpanel.org.uk/wpcontent/uploads/2008/11/code.pdf. Acesso em 19 de outubro de 2010.

31 "Section G. The voluntary offer and its terms - Rule 10.. It must be a condition of any offer for voting equity share capital or for other transferable securities carrying voting rights which, if accepted in full, would result in the offeror holding shares carrying over $50 \%$ of the voting rights of the offeree company that the offer will not become or be declared unconditional as to acceptances unless the offeror has acquired or agreed to acquire (either pursuant to the offer or otherwise) shares carrying over $50 \%$ of the voting rights. The City Code On Takeover and Mergers, $9^{\text {th }}$ edition, March 30, 2009. Disponível na internet: http://www.thetakeoverpanel.org.uk/wp-content/uploads/2008/11/code.pdf. Acesso em 19 de outubro de 2010.

${ }^{32}$ Neste mesmo sentido ver: CARVALHOSA, Modesto de Souza Barros. Op. Cit. p.170.

33 Art. 257, § $2^{\circ}$ "A oferta deverá ter por objeto ações com direito a voto em número suficiente para assegurar o controle da companhia e será irrevogável”.

${ }^{34}$ Neste sentido, Modesto Carvalhosa: "Atendendo à sua natureza, a lei expressamente declara a irrevogabilidade das ofertas públicas de aquisição de ações de controle (art. 257, §2º da Lei n ${ }^{\circ} 6.404$, de 1976). Essa característica também prevalece no caso de oferta concorrente (art. 262 da Lei n ${ }^{\circ} 6.404$, de 1976).” CARVALHOSA, Modesto de Souza Barros. Op. Cit. p.164. 
quando "tenha havido alteração substancial, posterior e imprescindível, nas circunstâncias de fato existentes quando do lançamento da OPA, acarretando aumento relevante dos riscos assumidos pelo ofertante, inerentes à OPA”.

Como a oferta pública de aquisição de controle exige registro prévio perante a CVM na hipótese de pagamento mediante permuta de ações ${ }^{35}$, esse dispositivo da CVM é frontalmente contrário ao que dispõe a Lei das Sociedades por Ações. Destarte, não caberá a CVM autorizar a sua revogação ou modificação, ainda quando for o caso de permuta de ações.

O ilustre Professor Carlos Augusto da Silveira Lobo considera que se aplica, por analogia, o artigo 478 do Código Civil nas hipóteses de onerosidade excessiva nos contratos de execução diferida ou continuada ${ }^{36}$. Contudo, como veremos mais adiante quando tratarmos da formação do contrato, não há que se falar em formação de contrato entre o ofertante e os acionistas da companhia alvo no momento da publicação do edital de oferta, muito menos afirmar que se trata de contrato de execução diferida. ${ }^{37}$

\footnotetext{
${ }^{35}$ Art. 259. O projeto de instrumento de oferta de permuta será submetido à Comissão de Valores Mobiliários com o pedido de registro prévio da oferta e deverá conter, além das referidas no artigo 258, informações sobre os valores mobiliários oferecidos em permuta e as companhias emissoras desses valores.

36 "Evidentemente, como o $\S 2^{\circ}$ do artigo 257 da LSA determina que a oferta pública para aquisição de ações de companhia aberta é irrevogável, não cabe à CVM autorizar sua revogação ou modificação, ainda quando seja de sua competência conferir registro. A nosso ver, aplica-se à hipótese o artigo 478 do Código Civil, que prevê a resolução dos contratos de execução diferida (e, por analogia, das propostas irrevogáveis) por onerosidade excessiva. Segundo o artigo 478, a resolução será decretada por sentença (nunca por decisão da CVM), 'se a prestação de uma das partes se tornar excessivamente onerosa, com extrema vantagem para a outra, em virtude de acontecimentos extraordinários e imprevisíveis’” LAMY FILHO, Alfredo e PEDREIRA, José Luiz Bulhões, et al. Op. Cit., p. 2039 ${ }^{37}$ A posição do ilustre Professor Calixto Salomão Filho também é contrária a este entendimento: “A oferta de tomada de controle é irrevogável (art. 257, §2º), Não se trata aí, de mera aplicação do direito contratual comum (Código Civil de 2002, art. 427), pois o ofertante não tem o direito de declarar a sua proposta retratável. Tal não significa, porém, a incolumidade do negócio aos efeitos da impossiblidade de fato, oriunda de caso fortuito ou força maior, nos moldes da chamada "out clause" da pratica norteamericana.” COMPARATO, Fabio Konder, SALOMÃO FILHO, Calixto. Op. Cit. p.258.
} 
O Código Civil afirma que o proponente está obrigado nos termos da sua proposta, entretanto o referido código prevê nos artigos 428 e 429 algumas hipóteses em que o ofertante não estará mais obrigado. Da mesma forma, não se aplicam, ao caso, as disposições previstas nos artigos 428 e 429 do Código Civil, pois o $\S 2^{\circ}$ do artigo 257 é norma específica e proíbe, expressamente, sem exceção, a revogação da oferta. Neste sentido posiciona-se Modesto Carvalhosa ${ }^{38}$ :

“A revogabilidade da oferta pública de aquisição de ações, se admitida, representaria um elemento permanente e gravíssimo de conturbação do mercado de valores mobiliários, pois ensejaria manobras especulativas de toda a espécie, ameaçando a estabilidade dos sistemas de poupança popular e da capitalização das companhias, bem como a administração destas últimas.”

Não obstante a disposição expressa na Lei das Sociedades por Ações, o Código Civil vigente já traz no seu artigo $427^{39}$ a obrigatoriedade da proposta feita pelo ofertante, salvo disposição expressa prevendo a possibilidade de retratação por parte do ofertante. O referido artigo não deve ser considerado contrário ao artigo 257, uma vez que a própria proposta admite a sua modificação ou a revogabilidade em determinadas condições que devem estar nela especificadas, ou seja, são condições da própria oferta. Contudo, não será admitida qualquer condição potestativa por parte do ofertante ${ }^{40}$, conforme proíbe o art. 122 do Código Civil ${ }^{41}$.

\footnotetext{
${ }^{38}$ CARVALHOSA, Modesto de Souza Barros. Op. Cit. p. 27

${ }^{39}$ Art. 427. A proposta de contrato obriga o proponente, se o contrário não resultar dos termos dela, da natureza do negócio, ou das circunstâncias do caso.

40 Neste sentindo, ensina o Professor Nelson Eizirik: “Isto não impede, contudo, conforme já mencionado, que o ofertante subordine a eficácia da oferta pública a condições, desde que tais condições não sejam potestativas, isto é, não dependam, para a sua implementação, da atuação direta ou indireta do ofertante ou de pessoas a ele vinculadas, conforme preceitua o artigo $4^{\circ}$, inciso VIII, da Instrução CVM no 361/2002.” EIZIRIK, Nelson. et. al., Op. Cit.

${ }^{41}$ Art. 122. São lícitas, em geral, todas as condições não contrárias à lei, à ordem pública ou aos bons costumes; entre as condições defesas se incluem as que privarem de todo efeito o negócio jurídico, ou o sujeitarem ao puro arbítrio de uma das partes.
} 
Existe também a hipótese em que a própria Lei das Sociedades por Ações ${ }^{42}$ e a Instrução $n^{0} 361$ da $C_{V V M}{ }^{43}$ permitem a modificação da oferta. É no caso da melhora do preço e das condições de pagamento que poderá ser efetuada apenas uma vez até o prazo de 10 dias do término da oferta.

Esta impossibilidade de retratação é bem rígida se compararmos com outras legislações como na Inglaterra, onde existe a possibilidade de retratação mediante a autorização do Panel on Takeover and Mergers, que é o órgão privado que regula as ofertas públicas das companhias abertas inglesas. Todavia, as mudanças econômicas de caráter conjuntural e político não são considerados pelo Panel como motivos suficientes para a retratação de uma oferta já efetuada. ${ }^{44}$

\subsection{Tipos de Oferta quanto a forma de liquidação financeira: moeda corrente, permuta, mista e alternativa.}

Conforme redação do artigo $6^{\circ}$ da Instrução CVM n 361, o ofertante poderá proceder à liquidação financeira da oferta através de moeda corrente, permuta de valores mobiliários ou uma forma mista, esta última significa quando o pagamento proposto é realizado parte em dinheiro e parte em valores mobiliários. Ainda nesse mesmo dispositivo, a CVM autoriza que a oferta seja alternativa, ou seja, os destinatários da oferta poderão escolher se desejam receber valores mobiliários ou dinheiro em troca de suas ações.

\footnotetext{
${ }^{42}$ Lei 6404/76 , art. $261 \S 1^{\circ}$ “É facultado ao ofertante melhorar, uma vez, as condições de preço ou forma de pagamento, desde que em porcentagem igual ou superior a 5\% (cinco por cento) e até 10 (dez) dias antes do término do prazo da oferta; as novas condições se estenderão aos acionistas que já tiverem aceito a oferta."

${ }^{43}$ Instrução n ${ }^{0}$ 361/02 CVM, Art. 5, § $4^{\circ}$ "Quando se tratar de modificação de OPA por melhoria da oferta em favor dos destinatários, ou por renúncia, pelo ofertante, a condição por ele estabelecida para a efetivação da OPA, presumir-se-á deferido o pedido caso não haja manifestação da CVM no prazo de 10 (dez) dias, contados do protocolo."

${ }^{44}$ CARVALHOSA, Modesto de Souza Barros. Op. Cit. p. 166
} 
A relevância da forma de liquidação financeira da oferta está na exigência de prévio registro na CVM em caso de permuta ${ }^{45}$, forma mista ou alternativa $^{46}$. O registro prévio da oferta acarretará uma série de exigências procedimentais reguladas pelos artigos 9 e 33 da Instrução n ${ }^{\circ} 361$ da CVM. Na oferta pública em que o proponente se obriga a liquidar mediante moeda corrente, não é necessário o registro prévio perante a CVM, bastando apenas que o ofertante comunique à CVM dentro de 24 horas da primeira publicação.

Via de regra, quando a liquidação financeira é realizada mediante pagamento em dinheiro, o preço ofertado pelo proponente supera consideravelmente o preço das ações cotadas no mercado. Nada impede, no entanto, que o preço ofertado seja exatamente o preço do mercado, isso ocorre quando as ações da companhia alvo apresentam pouca ou nenhuma liquidez. $\mathrm{O}$ preço é fixado pelo próprio mercado, desta forma, se o preço ofertado for pouco acima do valor de mercado, os acionistas de companhia podem entender que a oferta não está levando em consideração o fair market value, ou seja, a perspectiva de crescimento da empresa, o seu patrimônio líquido, seus ativos intangíveis e acabem por rejeitar a oferta. ${ }^{47}$

\subsubsection{Liquidação financeira através de permuta: formalidades e dificuldades.}

Conforme afirmado anteriormente, as ofertas em que a liquidação financeira se realiza através da permuta, da forma mista ou alternativa, deverão ser registradas previamente na CVM. Esse registro deve ser feito em até 30

\footnotetext{
45 Conforme exige a Lei $n^{\circ} 6.404 / 76$ em seu art. $257 \S 1^{\text {o: }}$ "Se a oferta contiver permuta, total ou parcial, dos valores mobiliários, somente poderá ser efetuada após prévio registro na Comissão de Valores Mobiliários”.

${ }^{46}$ Conforme dispõe a redação do artigo $6^{\circ}$, §2 ${ }^{\circ}$ da Instrução CVM no 361: "Às ofertas de permuta, mista e alternativa aplicam-se, além do procedimento geral desta Instrução, as disposições do art. 33.”

47 CARVALHOSA, Modesto de Souza Barros. Op. Cit. p. 155 e 156.
} 
dias a partir da publicação do primeiro fato relevante demonstrando a intenção do comprador em realizar a oferta, ou da deliberação que der notícia da realização da OPA, conforme exige o artigo $9^{\circ}$ da Instrução CVM n ${ }^{\circ} 361$. O registro deverá, ainda, observar os requisitos especificados no Anexo I da referida instrução. Após o registro, a CVM poderá realizar exigências e modificações na oferta.

Além dos requisitos aplicáveis às ofertas que não necessitem de registro, o instrumento da oferta pública a ser levado a registro deverá conter os requisitos indicados no artigo $33, \S 2^{\circ}$ da referida Instrução e até outros eventuais requisitos que a CVM entender necessários. Em poucas palavras, esses requisitos se constituem em informações detalhadas sobre os valores mobiliários oferecidos em permuta, as companhias emissoras desses valores, a relação de troca, dentre outras informações presentes nos incisos do referido parágrafo.

Somente poderão ser ofertados valores mobiliários de emissão de companhia aberta, admitidos a negociação em bolsa ou mercado organizado, ou seja, além das ações da própria companhia, podem ser emitidas em troca das ações objeto, ações de tesouraria, debêntures, partes beneficiárias conversíveis em ações e bônus de subscrição ${ }^{48}$. Nada impede que também sejam ofertados certificados emitidos por instituição financeira autorizada a operar no Brasil, lastreados em valores mobiliários de emissão de sociedade estrangeira, que possuam registro de companhia aberta perante a CVM, conforme estipula o artigo 33, §1 da Instrução nº 361 da CVM. ${ }^{49}$

\footnotetext{
${ }^{48}$ Idib. p.162.

49 LAMY FILHO, Alfredo e Pedreira, José Luiz Bulhões, et al. Op. Cit., p 2041.
} 
Além destes valores mobiliários, poderá, ainda, o ofertante oferecer valores mobiliários emitidos por outra companhia aberta que estejam na sua carteira. ${ }^{50}$

Segundo atenta o Professor Modesto Carvalhosa, as ofertas públicas de permuta são menos interessantes para os acionistas da companhia alvo, pois a permuta envolve a apreciação do efetivo valor dos títulos oferecidos em troca. ${ }^{51}$ Além disso, a oferta que tenha a moeda corrente como forma de liquidação financeira, é "mais atraente do ponto de vista psicológico para o acionista destinatário, pois lhe dá a possibilidade de auferir uma vantagem patrimonial imediata". 52

Além da desvantagem mercadológica, oferta de permuta apresenta uma série de dificuldades na sua preparação e execução, como oportunamente indicou o referido Professor:

“A primeira delas é a fixação dos próprios termos econômicos da permuta, que demanda uma comparação entre o valor de mercado e de rendimento dos valores objeto da permuta. Em segundo lugar, apresenta-se o problema dos valores mobiliários por emitir. Neste caso, a oferta não poderá estar sujeita à deliberação da Assembleia Geral, pois, ocorreria, na hipótese, uma condição potestativa, que é incompatível com o negócio da oferta. Dessa forma, somente as companhias de capital autorizado, com poderes de emissão delegados ao Conselho de Administração (art. 168, §1º, b, da Lei 6.404, de 1976) é que podem emitir ações que serão trocadas com aquelas da companhia visada pela oferta. Da mesma forma, apenas as companhias cuja Assembleia delegou poderes ao Conselho de Administração a deliberação sobre a oportunidade de emissão das debêntures é que podem lançar oferta de permuta desses títulos por ações de outra sociedade (art. 59, §1 ${ }^{\circ}$, da Lei 6.404, de 1976).

Ademais, no estatuto da companhia ofertante que contiver autorização para aumento de capital, deve estar prevista a emissão de valores mobiliários sem direito de preferência para os antigos acionistas na forma e para os efeitos do art. 172 da Lei $\mathrm{n}^{\circ}$ 6.404, de 1976. "53

\footnotetext{
${ }^{50}$ CARVALHOSA, Modesto de Souza Barros. Op. Cit. p.162

51 CARVALHOSA, Modesto de Souza Barros. Op. Cit. p. 155 e 156

${ }^{52}$ Ibid. p. 156

${ }^{53}$ CARVALHOSA, Modesto de Souza Barros. Op. Cit. p.161
} 
Apesar da permuta não envolver nenhum pagamento em dinheiro, não significa que o ofertante estará dispensado de ter como garantidor uma instituição financeira para a realização da oferta. O mesmo vale para a liquidação financeira em dinheiro e permuta de valores mobiliários, a instituição financeira está co-obrigada pela totalidade da liquidação, conforme exige o artigo 257 da LSA.

\subsection{Requisitos do instrumento da oferta. Edital.}

A publicação do edital ${ }^{54}$ de oferta pública de aquisição de controle é o instrumento através do qual a oferta do proponente se materializa e atinge os seus destinatários. Conforme o artigo 10 da Instrução CVM n³61, o edital deverá ser firmado tanto pelo ofertante quanto pela instituição financeira. Caso a oferta tenha como forma de liquidação financeira a permuta de valores mobiliários, o edital deverá conter a data do deferimento do registro perante a CVM, conforme exigência do artigo $11, \S 1^{\circ}$ da referida Instrução.

A CVM regula o instrumento mais detalhadamente através dos artigos 10 e 11 da Instrução $n^{0}$ 361, bem como pelo seu Anexo II. O artigo 258 da Lei 6.404/76 elenca os requisitos básicos do instrumento de oferta pública de aquisição de controle de companhia aberta. Neste sentido, o proponente deverá, no mínimo, indicar:

(i) A quantidade de ações que o ofertante se propõe a adquirir. Como visto no item 2.2 acima, não poderá ser inferior à quantidade mínima que lhe

\footnotetext{
54 Conforme exige o artigo 11 da Instrução CVM n 361: “O instrumento de OPA deverá ser publicado, sob a forma de edital, pelo menos uma vez, nos jornais de grande circulação habitualmente utilizados pela companhia objeto, observando-se o prazo máximo de 10 (dez) dias, após a obtenção do registro na CVM, quando este for exigível.”
} 
permita adquirir o controle. O proponente também poderá indicar o número máximo de ações que se compromete a adquirir. Caso haja um número de aceitantes detentores de ações em quantidade superior ao que o ofertante se comprometeu a adquirir, o rateio será obrigatório, ou seja, ele estará obrigado a adquirir um determinado percentual igual de todos os aceitantes, conforme regula o inciso III do artigo 258 da LSA.

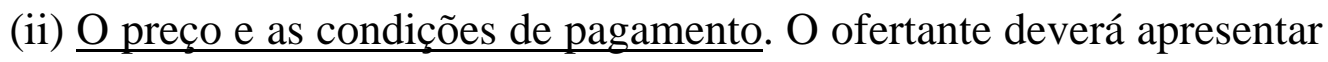
no instrumento o preço que se obriga a pagar pelas ações da companhia alvo. Conforme exige a Instrução CVM n 361 em seu inciso V do artigo $4^{\circ}$, a oferta pública de aquisição de controle deverá ser lançada por um preço uniforme. Existe a possibilidade de fixação de preços diferentes conforme a classe e espécie das ações objeto da oferta. Essa diferença deverá ser justificada pelo laudo de avaliação da companhia objeto ou por declaração expressa do ofertante, quanto às razões de sua oferta diferenciada. Cabe, ainda, ao ofertante, nos limites estabelecidos no $\$ 1^{055}$ do referido artigo, proporcionar aos acionistas aceitantes a possibilidade de receber a quantia a vista ou a prazo, desde que isso não afete a reflexão e a independência da decisão dos destinatários da oferta.

Caso a liquidação financeira seja através de permuta ou mista, ele deverá apresentar a relação de troca, a quantidade, espécie e classe dos valores mobiliários ofertados, os direitos legais e estatutariamente atribuídos a tais valores, seu histórico de negociação nos últimos 12 (doze) meses, e o

\footnotetext{
${ }^{55}$ Artigo $4^{\circ}, \S 1^{\circ}$ da Instrução CVM no 361/02: "Sem prejuízo do disposto no inciso V, a OPA poderá, se isto não violar outros dispositivos desta Instrução, ter preços à vista e a prazo distintos para os mesmos destinatários, desde que a faculdade de escolha caiba aos destinatários, haja justificada razão para sua existência, e tal distinção não afete a reflexão e a independência da decisão de aceitação da OPA, como por exemplo se estiver vinculada ao prazo de aceitação ou à quantidade de aceitações já manifestadas."
} 
tratamento a ser dado às eventuais frações decorrentes da relação de troca, sem prejuízo de outras informações consideradas necessárias pela CVM, conforme exige o §2 do artigo 33 da Instrução ${ }^{\circ} 361$ da CVM. O ofertante também está obrigado a apresentar um laudo de avaliação minucioso indicando os critérios de avaliação, de acordo com os termos especificados nos incisos do artigo $8^{\circ}$ da referida instrução da CVM.

O preço e as condições da oferta somente poderão ser alterados uma única vez pelo ofertante durante o procedimento da oferta, desde que o valor da nova oferta seja pelo menos 5\% superior à anterior, e essa alteração seja realizada em até 10 dias do término da oferta, conforme permite o $\S 1^{\circ}$ do artigo 261 da LSA. As novas condições se estenderão automaticamente aos acionistas que já tiverem manifestado a sua aceitação nas condições anteriormente publicadas. Na hipótese de um terceiro realizar uma oferta concorrente, a melhoria do preço e das condições será facultada ao primeiro ofertante. Destarte, cada ofertante poderá alterar o preço e as condições quantas vezes julgarem conveniente, conforme redação do $\S 3^{\circ}$ do artigo 13 da Instrução $\mathrm{CVM} \mathrm{n}^{\circ} 361 .{ }^{56}$

(iii) A subordinação da oferta ao número mínimo de aceitantes e a forma de rateio entre os aceitantes, caso o número deles ultrapassar o máximo fixado. Assim como afirmado no item (i) acima, o ofertante deverá, no

\footnotetext{
${ }^{56}$ Carlos Augusto da Silveira Souto apresenta um entendimento contrário. Ele afirma que cada ofertante apenas poderá aumentar o preço apenas uma única vez, conforme o $§ 1^{\circ}$ do artigo 261 da LSA., "Havendo uma oferta concorrente, a melhoria das condições é facultada para permitir ao primeiro ofertante concorrer em igualdade de condições com o ofertante concorrente, Desta forma, cada ofertante terá oportunidade de manifestar-se uma única vez diante da proposta do outro.” (LAMY FILHO, Alfredo e PEDREIRA, José Luiz Bulhões, et al. Op. Cit., p 2042). Entretanto este não é o entendimento mais correto. Este parágrafo está contido no artigo 261 que se refere ao procedimento da oferta, já a oferta concorrente, que está regulada no 262, não há restrição quanto ao número de vezes que o preço poderá ser melhorado. Como o artigo 263 da LSA afirma que a CVM poderá expedir normas que disciplinem a negociação das ações objeto da oferta, devemos considerar que a permissão contida no $\S 3^{\circ}$ do artigo 13 da Instrução CVM n ${ }^{0} 361$ é legítima.
} 
mínimo, comprometer-se a comprar uma quantidade que lhe assegure o controle da companhia objeto. Entretanto, ele poderá ir além, poderá limitar a eficácia da aquisição de acordo com a quantidade de ações que ele desejar. Caso essa quantidade não seja atingida, ele não estará obrigado a comprar uma ação sequer.

Na hipótese em que o número de aceitantes seja superior ao que ele se obrigou a comprar, o rateio será obrigatório. Dessa forma, o ofertante deverá indicar o mecanismo pelo qual esse rateio será feito. Para fins de exemplo, a oferta pública de aquisição do controle da Paranapanema S.A. e da GVT (Holding) S.A., que acabaram por não serem bem sucedidas, não limitavam o número de ações que as ofertantes poderiam adquirir. Não é raro que os ofertantes se comprometam a comprar até 100\% das ações de uma companhia, pois muitas vezes possuem a intenção de fechar o capital da companhia após a aquisição. Além disso, quando um ofertante se obriga a comprar 100\% do capital acaba por estimular os acionistas a venderem suas ações, pois caso haja uma forte aceitação em virtude do preço, as ações remanescentes correrão o risco de perder liquidez. ${ }^{57}$

(iv) $\underline{O}$ procedimento que deverá ser adotado pelos acionistas aceitantes para manifestar a sua aceitação e efetivar a transferência de ações. O ofertante deverá descrever qual será o procedimento pelo qual os acionistas deverão aceitar a proposta, levando em considerações as exigências legais do artigo 261 da LSA e do artigo 12 da Instrução CVM n 361 . O momento e o procedimento da aceitação, tal como o seu caráter irrevogável serão tratados com mais atenção no tópico referente à aceitação. Em relação à efetivação da

\footnotetext{
${ }^{57}$ Este foi o entendimento dos analistas do mercado em relação à oferta pública de aquisição de ações preferenciais da NET pela Embratel. Conforme está disponibilizado no sitio: http://veja.abril.com.br/noticia/economia/embratel-compra-mais-de-70-das-acoes-preferenciais-da-netem-leilao. Acesso em 21 de outubro de 2010.
} 
transferência, o ofertante deverá informar aos destinatários da oferta, o procedimento da transferência de ações ou dinheiro em troca das ações alienadas.

(v) $\underline{O}$ prazo de validade da oferta que não poderá ser inferior a 20 dias. O legislador indicou um prazo mínimo considerável para que o acionista da companhia alvo possa avaliar se deseja ou não alienar suas ações. Entretanto, o legislador não quis limitar o prazo máximo pelo qual a oferta deverá permanecer em aberto. Deve-se levar em consideração que se a oferta se prolongar por um tempo excessivo, poderá causar prejuízos a companhia alvo, pois, sem dúvida, a oferta altera o curso normal das atividades da empresa, uma vez que ela está sob uma oferta de aquisição, provocando, assim, uma insegurança no mercado e uma variação atípica da cotação das ações na bolsa de valores em que a companhia esteja listada. ${ }^{58}$

Diferentemente do inciso V do artigo 258 da LSA, a Instrução CVM nº 361, em seu artigo 12, §1, define que a aceitação da oferta pública ocorrerá durante o leilão, e que esse deverá ser realizado no prazo mínimo de 30 dias e máximo de 45 dias contados da data de publicação do edital. Resta ao ofertante saber qual prazo seguir. Como a CVM não estabeleceu prazo mínimo inferior ao da lei, o ofertante não correria o risco de incorrer em ofensa ao artigo 258 da LSA. Juridicamente, a instrução da CVM é hierarquicamente inferior,

\footnotetext{
${ }^{58}$ Conforme regula a Directiva 2004/25/CE do Parlamento Europeu e do Conselho de 21 de abril de 2004, relativa às ofertas públicas de aquisição, em seu artigo $3^{\circ}$, onde define os princípios gerais, ${ }^{\circ} 1$, alínea f), "A sociedade visada não deve, em virtude de uma oferta respeitante aos valores mobiliários, ser perturbada, no exercício de sua actividade para além de um período razoável.” E ainda no artigo $7^{\circ}$, sobre o prazo de aceitação, dispõe o seguinte: "Os Estados-Membros asseguram que o prazo de aceitação da oferta não seja inferior a duas semanas, nem superior a 10 semanas a contar da data de publicação do documento relativo à oferta. Sem prejuízo do princípio geral enunciado na alínea f) do $\mathrm{n}^{\circ} 1$ do artigo $3 .^{\circ}$, os Estados-Membros podem estabelecer a possibilidade de prorrogação do prazo de 10 semanas, na condição de o oferente notificar, com antecedência de, pelo menos, duas semanas, a sua intenção de encerrar a oferta.” Disponível no site: http://eurlex.europa.eu/LexUriServ/LexUriServ.do?uri=OJ:L:2004:142:0012:0012:PT:PDF. Acesso realizado em 02 de novembro de 2010.
} 
devendo, assim, prevalecer a lei ordinária. Contudo, devemos atentar para o fato de que a CVM pode criar problemas para o ofertante. Desta forma, entendemos mais prudente seguir à risca as disposições dessa instrução, mesmo que elas sejam divergentes da LSA. ${ }^{59}$

(iv) Informações sobre o ofertante. O dever de informar o destinatário da oferta cabe tanto ao ofertante quanto à instituição financeira que está coobrigada pelas declarações presentes no instrumento de oferta. O objetivo das informações é de proteger os interesses dos acionistas da companhia visada e dos investidores do mercado. ${ }^{60}$ Um dos princípios gerais da Instrução CVM n 361 , está disposto em seu artigo $4^{\circ}$, inciso II, em que requer um tratamento equitativo tanto aos destinatários da oferta, permitindo-lhes a adequada informação quanto à companhia objeto e ao ofertante, e disponibilizando os elementos necessários para que estes possam tomar uma decisão refletida e independente quanto à aceitação da oferta.

As informações sobre ofertante são devidas, basicamente para que o acionista da companhia alvo saiba para quem está vendendo as suas ações. Isso é de extrema relevância, uma vez que o ofertante possa estar utilizando uma empresa veículo para adquirir o controle da companhia do seu concorrente sem que ele saiba. Dessa forma, as informações básicas do ofertante devem estar disponibilizadas no edital, como por exemplo, quem são seus controladores, a sede, o seu objeto social, setores de atuação, histórico e capital social. O inciso

59 Além disso, devemos considerar que a regulamentação da oferta pública de aquisição de controle está inalterada desde 1976 e esta oferta é muito complexa para ser regulada em apenas poucos artigos. Em países em que a oferta pública de aquisição de controle é mais praticada, quem regula o assunto são órgãos administrativos como a Securities Exchange Comission, conjuntamente com o Williams Act, ou por instituições corporativas como na Inglaterra que quem regula é o Panel on Takeovers and Mergers através do Code on Takeovers and Mergers. Na Europa, existe uma diretiva de 2004 que dita as regras básicas que os Estados-Membros devem implementar em seus países.

${ }^{60}$ CARVALHOSA, Modesto de Souza Barros. Op. Cit. p. 190. 
II do artigo 32 da Instrução CVM n 361 ainda requer que sejam divulgadas as mesmas informações exigidas na oferta pública de alienação de controle.

A minuta da instrução da CVM presente no Edital de Audiência Pública $n^{0}$ 02/10, que altera a Instrução CVM n ${ }^{0} 361$, requer novos prazos para a publicação do edital. No caso de oferta pública de aquisição de controle com permuta de ações, mista ou alternativa, a publicação do edital deverá ser realizada até 10 dias da obtenção do registro perante a CVM. Na hipótese da liquidação financeira da oferta pública ser realizada em dinheiro, ou seja, não sujeita a registro, o prazo para publicação do edital será de 30 dias contados do anúncio da oferta 4-B da minuta.

\subsection{Aceitação da Oferta e o Leilão.}

O acionista da companhia alvo que detiver ações da mesma classe e espécie objeto da oferta pública de ações deverá manifestar a sua aceitação na forma que estiver prevista no edital de oferta ${ }^{61}$. Essa forma, descrita pelo ofertante, deverá conter mínimos procedimentos exigidos pela LSA e pela Instrução n³61 da CVM, os quais foram especificados no sub-capítulo acima.

O artigo 261 da Lei das Sociedades por Ações determina que a aceitação deverá ser manifestada perante instituições financeiras ou do mercado de valores mobiliários indicadas no instrumento de oferta. A aceitação não deverá ser necessariamente feita perante a instituição

\footnotetext{
61 O instrumento de oferta deverá prever a forma pela qual proceder-se-á a aceitação, conforme será exigida pelo inciso IV do artigo 258 da LSA: “Art. 258. O instrumento de oferta de compra, firmado pelo ofertante e pela instituição financeira que garante o pagamento, será publicado na imprensa e deverá indicar: IV - o procedimento que deverá ser adotado pelos acionistas aceitantes para manifestar a sua aceitação e efetivar a transferência das ações.”
} 
intermediária, apesar desse mecanismo ser usualmente indicado pelo ofertante. $^{62}$

Ainda conforme o artigo acima referido, uma vez realizada a aceitação pelo acionista alienante, essa torna-se irrevogável, ficando o aceitante obrigado a alienar o número de ações que se dispôs a vender nos termos e condições presentes no edital de oferta. A exceção legal à irrevogabilidade da aceitação ocorre na hipótese de surgimento de uma oferta concorrente à oferta inicial, na forma do $\S 1^{\circ}$ do artigo 262 da LSA.

Entretanto, conforme vimos anteriormente, o ofertante não estará obrigado a efetivar a aquisição caso o número de aceitações não atinja a quantidade mínima estabelecida no edital de oferta. Dessa forma, a oferta somente será considerada bem sucedida e o aceitante somente poderá alienar suas ações no momento em que o número de aceitantes alcançar o mínimo de ações que o ofertante se obrigou a adquirir.

Diferentemente do direito brasileiro, o Willians Act no item 14 (d) (5) ${ }^{63}$, que regulamenta as tender offers nos Estados Unidos, é mais favorável ao investidor facultando-lhe a possibilidade de retirar a sua aceitação durante o decurso da oferta, conforme ensinam os Professores Guido Ferrarini e

${ }^{62}$ Conforme foi possível observar no item 2.1 (Habilitação) da Oferta Pública Voluntária para Aquisição de Ações Ordinárias da Paranapanema S.A.: "2.1. Habilitação. O Acionistas interessado em alienar as suas ações no Leilão deverá habilitar-se, no período compreendido entre a data de publicação deste Edital e até as 18:00 horas do Dia Útil imediatamente anterior à Data do Leilão, junto a Bradesco Corretora ou outra sociedade corretora ou distribuidora de sua escolha que seja autorizada a operar na BM\&FBOVESPA, (“Corretora”), segmento Bovespa, de forma que tal Corretora possa representá-lo no Leilão.

${ }_{63}$ Neste sentido ver Securities Exchange Act 1934, 14(d)(5) "Securities deposited pursuant to a tender offer or request or invitation for tenders may be withdrawn by or on behalf of the depositor at any time until the expiration of seven days after the time definitive copies of the offer or request or invitation are first published or sent or given to security holders, and at any time after sixty days from the date of the original tender offer or request or invitation, except as the Commission may otherwise prescribe by rules, regulations, or order as necessary or appropriate in the public interest or for the protection of investors.” Disponível na internet: www.sec.gov Acesso: 30 de outubro de 2010. 
Geoffrey P. Miller: "As implemented by the SEC, the Williams Act contains other protections for shareholders of the target firm. For example, shareholders are permitted to withdraw their shares as long as the BID remains open." 64

A regulamentação norte-americana possibilita que o oblato possa retratar a sua aceitação em dois diferentes momentos: em até sete dias após o lançamento da oferta; e a qualquer momento após sessenta dias decorridos a partir dessa mesma data. Conforme ensinam Luiza Rangel de Morares e Maria Isabel do Prado Bocater ${ }^{65}$ sobre esta possibilidade de retirada (withdraw) no direito norte-americano:

"Este dispositivo existe porque não há previsão legal ou regulamentar de prazo
mínimo de duração de uma oferta pública e, sendo assim pretende evitar fique o
destinatário sujeito à retenção de seus títulos por um período até que o ofertante
decida sobre comprá-los ou não.”

A Instrução CVM nº 361 define, em seu artigo 12, que a oferta pública de aquisição de ações será efetivada em leilão e, em seu $\S 6^{\circ}$, faculta ao ofertante, no caso da oferta pública para aquisição de controle, uma vez autorizado pela CVM, a efetivação da oferta através de outro procedimento diverso do leilão. Entretanto, observando as práticas recentes de ofertas públicas para aquisição de controle, o mecanismo de efetivação usualmente escolhido pelos ofertantes foi o leilão. ${ }^{66}$

\footnotetext{
${ }^{64}$ FERRARINI, Guido e MILLER, Geoffrey P., A simply Theory of Takeover Regulation in the United States and Europe. Cornell International Law Journal. Vol. 42. 2010. Disponível na internet no sítio: http://organizations.lawschool.cornell.edu/ilj/issues/42.3/CIN301.pdf. Acesso realizado em 25 de setembro de 2010.

${ }_{65}$ MORARES, Luiza Rangel de; BOCATER, Maria Isabel do P. Oferta Pública de Aquisição do Controle (Art. 257 e seguintes da Lei $n^{\circ}$ 6.404/76) Estudo Jurídico Básico, Gerência de Legislação e Pesquisa, Superintendência Jurídica. Rio de Janeiro: Legis Bancos, 1980. p 142.

${ }^{66}$ Entretanto, pôde-se observar nas últimas ofertas públicas para aquisição de controle no Brasil, os ofertantes utilizaram o leilão como forma de efetivação da oferta, Conforme podemos observar no Edital de Oferta Pública Voluntária para Aquisição de Ações Ordinárias de Emissão da Paranapanema. Publicado no Diário Oficial do Estado do Rio de Janeiro, Ano XXXVI - No 139 - Parte V - Rio de
} 
Conforme afirmado anteriormente, caso ocorra um número de aceitações que seja superior ao limite máximo de ações que o ofertante se dispôs a adquirir, proceder-se-á obrigatoriamente a rateio, na forma descrita no edital, e nos termo do artigo 261 da LSA. Nesse sentido, o Professor Modesto Carvalhosa ensina que "este rateio será rigorosamente proporcional ao número de ações objeto de aceitações.”67

Na mesma forma da legislação americana, ${ }^{68}$ a legislação brasileira prevê que, em caso de ocorrência de aumento de preço por parte do ofertante, os acionistas que já haviam aderido à oferta sejam beneficiados automaticamente por esse aumento, nos termos do $\S 1^{\circ}$ artigo 261 da LSA. Essa é uma forma de dar igualdade de benefícios a todos acionistas detentores das ações visadas. Isso impede que um determinado acionista que detenha um volume de ações receba em troca de suas ações um valor superior aos demais acionistas com pequena participação. É, ainda, uma forma de proteger os investidores, o que é uma característica marcante da legislação americana sobre takeovers. ${ }^{69}$

Janeiro, terça-feira - 3 de agosto de 2010, e na Republicação do Edital de Oferta Púluca Voluntária de aquisição de Ações Ordinárias de Emissão da GVT (Holding) S.A.. Disponível em http://www15.telefonica.com.br/investidores/sp/download/edital_OPA_novo_preco_051109.pdf.

Acesso em18 de novembro de 2010. Neste acaso a oferta realizada pela Telefônica era uma oferta concorrente à efetuada pela Vivendi em 8 de setembro de 2009.

${ }^{67}$ CARVALHOSA, Modesto de Souza Barros. Op. Cit. p. 184.

${ }^{68}$ Neste sentido ver Securities Exchange Act 1934, 14(d)(7) "Where any person varies the terms of a tender offer or request or invitation for tenders before the expiration thereof by increasing the consideration offered to holders of such securities, such person shall pay the increased consideration to each security holder whose securities are taken up and paid for pursuant to the tender offer or request or invitation for tenders whether or not such securities have been taken up by such person before the variation of the tender offer or request or invitation."

${ }^{69}$ Conforme ensinamento de Guido Ferrarini e Geoffrey P. Miller: "Congress attempted to create a level of playing field between targets and bidders by attempting to empower investors to make decisions without compulsion and on basis of full and complete information.” FERRARINI, Guido e MILLER, GEOFFREY P., Op. Cit. Disponível na internet no sítio: http://organizations.lawschool.cornell.edu/ilj/issues/42.3/CIN301.pdf. Acesso realizado em 25 de setembro de 2010. 
A redação do $\S 1^{\circ}$ do referido artigo, dispõe que a aceitação será realizada durante o leilão. Isso significa que desde o momento da publicação do edital até o dia efetivo do leilão, os acionistas detentores das ações objeto da oferta poderão avaliar se desejam ou não aceitar a oferta no dia do leilão a ser realizado na bolsa de valores ou no balcão de mercado organizado.

A forma de aceitação da oferta pública para aquisição de controle da Paranapanema, por exemplo, trouxe uma sistemática interessante para que os acionistas da empresa alvo pudessem aderir à oferta. Essa forma foi descrita no item 2 do edital publicado no Diário Oficial do Estado do Rio de Janeiro em 3 de agosto de 2010, bem como no Ofício Circular 032/2010-DP da BM\&FBOVESPA, publicado em 23 de agosto de 2010. Este último, em seu item 1 , traz a seguinte redação:

“O Acionista da Paranapanema que desejar alienar suas ações no Leilão deverá habilitar-se até as 18h do Dia Útil imediatamente anterior ao dia 01/09/2010 ("Data do Leilão"), junto a qualquer sociedade corretora ou distribuidora de sua escolha que esteja autorizada a operar no sistema de negociação da Mega Bolsa do segmento Bovespa da BM\&FBOBESPA, (“Corretora”), Conforme as normas regulamentares e operacionais constantes no Edital.”

Podemos observar que o referido dispositivo apresenta o procedimento de habilitação ao leilão, o qual deverá ser feito dentro do prazo da oferta, para que, após habilitado a participar do leilão, o acionista possa alienar suas ações. A inovação desse edital publicado pela Vale, está na possibilidade dos acionistas aceitantes registrarem ordens de venda no leilão por um preço superior ao preço que o ofertante se dispôs a pagar, conforme podemos observar no item 2.2.1 do edital e no item 8 do referido ofício circular:

“Até as 12:00 horas (horário de Brasília) da Data do Leilão, as Corretoras deverão registrar as ordens de venda com a quantidade de Ações Objeto dos acionistas aceitantes da Oferta que serão por elas representadas no Leilão (“Ordens de Venda”), caso aplicável, no sistema de MegaBolsa, sob o código PMAM3L. As ofertas de 
venda poderão ser registradas por preço superior ao da Oferta, podendo, a qualquer momento durante a realização do Leilão, terem seus preços reduzidos.”

Cabe agora analisar se esse procedimento contraria o que disciplina a LSA. O artigo 261 da LSA define que "os aceitantes deverão firmar ordens irrevogáveis de venda ou permuta, nas condições ofertadas”. Além disso, o §1 do artigo 12 da Instrução CVM n ${ }^{0} 361$ estabelece que a aceitação ou não da OPA dar-se-á no leilão e "obedecerá às regras estabelecidas pela bolsa de valores ou pela entidade do mercado de balcão organizado responsável pelo leilão”. Nesse sentido, as ordens irrevogáveis de venda por um preço superior ao da oferta só podem existir havendo previsão no edital da oferta pública. Além disso, tal mecanismo de aceitação está estabelecida também no Ofício Circular 032/2010-DP, publicado pela BM\&FBOVESPA obedecendo, assim, o disposto no referido artigo 12.

Apesar de não existir qualquer vedação legal para que o aceitante faça uma ordem de venda por um preço superior ao da oferta, o $§ 1^{\circ}$ do artigo 261 da lei das LSA apenas permite que o ofertante eleve o preço da oferta em no mínimo 5\% ao preço anterior e em até 10 dias antes do término da oferta. Dessa forma, caso o aceitante exerça a opção de realizar uma ordem de venda por um preço superior ao da oferta, o ofertante não poderia aumentar o seu preço para adquirir estas ações, uma vez que não poderá mais aumentá-lo, pois seu direito decaiu. ${ }^{70}$ Esse procedimento impossibilitaria a alienação, uma vez que o preço da oferta nunca atingiria o da ordem de venda.

\footnotetext{
70 Isso se considerarmos que o disposto no inciso I do§ $2^{\circ}$ do artigo 12 da Instrução CVM n³61 é contrário à lei, pois o $\$ 1^{\circ}$ do artigo 261 da LSA apenas permite uma única elevação de preços em determinadas condições. Sendo a LSA hierarquicamente superior à Instrução da CVM, o disposto nesta instrução não deverá ser considerado legal.
} 
Nesse caso específico, não há dúvidas que o edital está seguindo as regras estabelecidas no inciso I, do $\S 2^{\circ}$ do artigo 12 da Instrução $361^{71}$, esse inciso é frontalmente contrário ao que estabelece o artigo 261, $\$ 1^{072}$. A vedação prevista nesse parágrafo tem por objetivo evitar que o ofertante fique testando o mercado ao oferecer diversos preços até que consiga a quantidade de aceitações necessárias à efetivação da oferta.

Também não é valida a interpretação de que a vedação do artigo 261 não se aplica ao procedimento do leilão e que esse não está dentro do prazo da oferta, pois o referido artigo é claro ao afirmar somente é permitido aumentar a oferta até 10 dias antes do término da oferta, sendo que o leilão integra o período da oferta, conforme pode-se observar na redação do $\S 2^{\circ}$ do artigo em análise: "Findo o prazo da oferta, a instituição financeira intermediária comunicará o resultado à Comissão de Valores Mobiliários e, mediante publicação pela imprensa, aos aceitantes”. Destarte, é nítido que o leilão integra o prazo da oferta.

A CVM está reparando essa contradição com o artigo 261, no Edital de Audiência Pública para alterar a Instrução CVM n 361. O §2 ${ }^{\circ}$, artigo 12 da minuta da nova instrução traz a vedação de elevação do preço na data da realização do procedimento especial que substituirá o leilão, sendo este último um procedimento que poderá ser utilizado no caso de oferta pública concorrente.

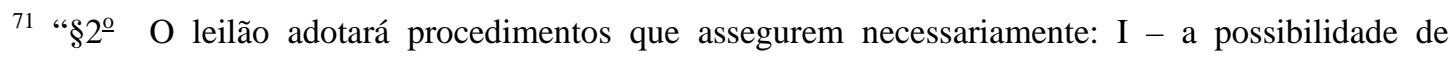
elevação do preço a ser pago pelas ações durante o leilão, estendendo-se o novo preço a todos os acionistas aceitantes dos lances anteriores, observada a diferenciação de preços entre as diversas classes ou espécies de ações, se houver, e a possibilidade de elevação do preço apenas para uma ou algumas classes ou espécies de ações.”

72، $261, \S 1^{\circ}$ É facultado ao ofertante melhorar, uma vez, as condições de preço ou forma de pagamento, desde que em porcentagem igual ou superior a 5\% (cinco por cento) e até 10 (dez) dias antes do
} 
O procedimento indicado no edital de aquisição da Paranapanema S.A. não é contrário à lei, entretanto a Vale não poderia aumentar o preço no momento do leilão, pois estaria indo de contra o disposto no artigo 261 da LSA.

\subsection{Sigilo.}

O artigo 260 da LSA determina que o proponente, a instituição financeira, a bolsa de valores $^{73}$ e a CVM deverão manter sigilo sobre a operação, podendo responder, o infrator, pelos danos que vier a causar. Obviamente, o dever de sigilo é referente ao período em que a oferta ainda não for publicada, sendo essa a fase secreta, onde o ofertante está realizando os estudos de viabilidade, deliberando sobre o tema, contatando a instituição financeira garantidora, e requerendo registro perante a CVM, caso escolha a permuta ou a forma mista como forma de pagamento.

O objetivo do artigo 260 é prevenir que essas informações sejam publicadas antes do devido momento, pois nem sua ocorrência, tão pouco seus detalhes estão definidos. Dessa forma, qualquer vazamento ensejaria expectativas, especulações e confusão no mercado o que poderia acarretar prejuízos financeiros tanto para as companhias envolvidas, quanto para seus acionistas. Nesse sentido, ensina o ilustre Professor Modesto Carvalhosa: “O preceito visa manter o funcionamento regular do mercado e evitar o surgimento de condições artificiais de demanda, oferta e preço dos valores mobiliários envolvidos na futura proposta pública." ${ }^{74}$

término do prazo da oferta; as novas condições se estenderão aos acionistas que já tiverem aceito a oferta."

${ }^{73}$ Modesto Carvalhosa entendeu por bem incluir a bolsa de valores, o que faz sentido, uma vez que ela poderá conhecer da operação durante a fase secreta. CARVALHOSA, Modesto de Souza Barros. Op. Cit. p. 176.

${ }^{74}$ Ibid. p. 176. 
Como observado acima, o sigilo é de interesse de todas as partes envolvidas, em especial do ofertante, caso ele pretenda realizar uma oferta agressiva de aquisição de controle. Na hipótese de vazamento de informação nesse tipo de operação, os administradores e acionistas da companhia alvo poderão utilizar manobras societárias com o intuito de frustrar a tentativa de aquisição para que mantenham suas posições atuais. ${ }^{75}$

Caberá a CVM fiscalizar o cumprimento do dever de sigilo pelas partes envolvidas, incluindo os seus próprios funcionários, a fim de proteger os investidores e a regularidade do mercado. A quebra de sigilo acarreta responsabilidade civil e administrativa aos seus infratores. ${ }^{76}$

Para fins de comparação, a legislação inglesa (Code on Takeovers and Mergers) trata do assunto com muita cautela ${ }^{77}$. Nesse país existe a necessidade de comunicação ao Board da empresa alvo antes da publicação da oferta. ${ }^{78}$ Em virtude disto, anteriormente a esse approach, o ofertante e seus consultores estão exclusivamente responsáveis pelo sigilo da operação devendo, inclusive, verificar o comportamento das ações da companhia alvo ${ }^{79}$, pois qualquer variação anormal poderá significar que houve um vazamento de informações.

\footnotetext{
${ }^{75}$ Este é o mesmo entendimento do Professor Modesto Carvalhosa. Ibid. p. 176.

${ }^{76}$ Ibid. p. 177.

${ }^{77}$ Conforme podemos observar com a redação da RULE 2.1: "SECRECY The vital importance of absolute secrecy before an announcement must be emphasized. All persons privy to confidential information, and particularly price-sensitive information, concerning an offer or contemplated offer must treat that information as secret and may only pass it to another person if it is necessary to do so and if that person is made aware of the need for secrecy. All such persons must conduct themselves so as to minimize the chances of an accidental leak of information."

${ }^{78}$ Conforme exigência da RULE 1 da SECTION D do Code on Takeover and Mergers: "(a) The offer must be put forward in the first instance to the board of the offeree company or to its advisers."

${ }^{79}$ Conforme regula a RULE 2.3 do Code on Takeover and Mergers: "Before the board of the offeree company is approached, the responsibility for making an announcement can lie only with the offeror. The offeror should, therefore, keep a close watch on the offeree company s share price for any signs
} 


\subsection{Aspecto Contratual.}

Como vimos acima, a oferta pública constitui uma declaração de vontade irrevogável do proponente dirigida à incertam personam, válida por um prazo determinado, de adquirir um quantidade mínima de valores mobiliários específicos a um determinado preço, segundo as cláusulas e condições também previamente determinadas. Essa declaração pública de vontade é materializada através do edital.

Consideramos importante fazer uma análise estrutural de uma oferta pública de aquisição de controle. Segundo, o ilustre Professor Fabio Konder Comparato, não há na oferta pública para aquisição de controle uma identidade de objeto na manifestação de vontade do ofertante e a do aceitante.

Concordamos com esta afirmativa, pois, de um lado, temos o objeto da vontade do ofertante que é o bloco de ações que lhe garanta o controle majoritário e, de outro lado, temos o acionista individual que tem por objeto a vontade de aderir à oferta somente com as ações que possui. Sendo assim, não podemos ter um contrato em que os objetos da manifestação de vontade das partes seja diferente. Dessa forma, entendemos que o contrato só se concretiza quando é atingida a condição de adesão de um número de acionistas que representem 50\% mais uma ação da companhia. Só a partir desse momento que o contrato passará a existir.

O referido autor adverte que não se trata de um contrato com condição suspensiva ou de um contrato preliminar, este último defendido por Modesto

of untoward movement. The offeror is also responsible for making an announcement once a obligation has been incurred Rule 9." 
Carvalhosa $^{80}$. Em relação à condição suspensiva, Comparato afirma que os efeitos do contrato não passam a serem efetivos após a adesão do acionista que garanta o 50\% mais uma ação, na verdade, até esse momento, não existia contrato algum.

“A explicação pela teoria da condição suspensiva representa, de fato, um deslizamento do objeto do acordo de vontades para efeitos do acordo já formado. Sendo a condição um cláusula, derivada exclusivamente da vontade das partes, que subordina os efeitos do ato jurídico a evento futuro e incerto (CC de 2002, art. 121), ela pressupõe um ato jurídico perfeito e acabado - no caso, um contrato já formado para regular tão só os efeitos deste ato, no efeito suspensivo e resolutório. Ora, na oferta pública de aquisição de ações, não há contrato já formado enquanto não obtidas todas as aceitações individuais necessárias a compor um bloco de controle, porque este é, na verdade, o objeto da oferta da aquisição." ${ }^{1}$

Em relação ao contrato preliminar, Fabio Konder Comparato afirma que :

"Tampouco acolhível, em nosso entender, a teoria do contrato preliminar. Para que ela apresentasse um mínimo de verossimilhança, seria mister identificar o momento da contratação definitiva, o que supõe nova manifestação de vontade das partes. Mas essa nova emissão volitiva não existe. A colaboração ulterior dos contratantes não é para formar definitivamente o contrato e, sim, para executar as obrigações dele decorrentes, a saber, a transferência da titularidade das ações e o pagamento do preço.”

Excluídas aquelas formas de contrato, que tipo de contrato é formado quando se atinge um número de acionistas capaz de representar o controle da companhia?

Segundo o referido autor o contrato entre os aceitantes e o ofertante é um contrato grupal, onde de um lado está o ofertante e do outro estão todos os aceitantes "formando uma parte plúrima, isto é, um mesmo centro de interesses coincidentes, embora não comuns.”,82

\footnotetext{
${ }^{80}$ CARVALHOSA, Modesto de Souza Barros. Op. Cit.. p. 49 e ss.

${ }^{81}$ COMPARATO, Fabio Konder e SALOMÃO FILHO, Calixto. Op.Cit. p. 255.

${ }^{82}$ Ibid. p. 256.
} 


\section{Oferta pública concorrente.}

A oferta pública concorrente está regulamentada no artigo 262 da LSA e no artigo $13^{\circ}$ da Instrução CVM n ${ }^{0} 361$. Essa acarretará imediatamente a anulação das ordens de venda efetuadas pelos aceitantes da oferta anterior. Em virtude disso, a lei concede ao primeiro ofertante a possibilidade de estender o prazo da sua oferta inicial até a data do término do prazo da oferta concorrente.

Conforme observou Modesto Carvalhosa, no Brasil, ao contrário de outras legislações, não se faculta ao primeiro ofertante a possibilidade de desistir de sua oferta anterior ${ }^{83}$, continuando o mesmo obrigado a cumprir com a sua oferta inicial, tendo apenas o direito de melhorá-la apenas uma vez, conforme o artigo 261, §1 ${ }^{\circ}$ da LSA.

A oferta concorrente deverá seguir os mesmos requisitos legais que se aplicam à oferta do artigo 257, devendo o instrumento da oferta pública conter todas as especificações exigidas na LSA, bem como na Instrução $n^{0} 361$ da CVM. Além dessas, a mesma instrução, em seu artigo $13, \S 3^{\circ}$, requer que esta oferta concorrente seja, no mínimo, 5\% superior ao da oferta do primeiro ofertante.

Conforme afirmando anteriormente, a oferta pública concorrente irá ensejar a anulação das aceitações à primeira oferta realizadas pelos acionistas da companhia alvo (art. 262, §1 ${ }^{\circ}$, LSA). Ocorre que a instrução da CVM afirma que as aceitações dar-se-ão apenas no momento do leilão (art. 12, §1 ${ }^{\circ}$ ), sendo assim, apenas existirão aceitações a serem anuladas, caso seja publicada oferta concorrente no próprio dia do leilão. 
Tendo em vista a referida instrução da CVM e o que dispõe a LSA sobre oferta concorrente, verifica-se, mais uma vez, a incompatibilidade entre aos dois diplomas. Conforme regula o $\$ 1^{\circ}$ do artigo 261 da LSA, o ofertante terá direito a aumentar o preço de sua oferta uma vez apenas e desde que apresente oferta 5\% maior do que a anterior. Entretanto, a instrução da CVM dispõe de forma diversa em seu $\S 3^{\circ}$, permitindo que, uma vez lançada a oferta concorrente, tanto o ofertante inicial quanto o concorrente possam aumentar o preço de suas ofertas tantas vezes quanto julgarem conveniente, desde que cada aumento seja público. Esse artigo demonstra claramente a intenção da CVM em estimular a competição e a elevação do preço da oferta pelas ações da companhia alvo.

Uma parte da doutrina se posicionou de forma oposta ao que estabelece a CVM, como podemos observar no entendimento de Carlos Augusto da Silveira Lobo:

"Nos termos do $\S 1^{\circ}$ do artigo 261 da LSA, acima comentado, poderá o primeiro
ofertante melhorar sua oferta original para competir com a oferta concorrente. (...)
Somente o primeiro ofertante poderá uma única vez melhorar a sua oferta, nos termos
do $\S 1^{\circ}$ do artigo 261 da LSA. O ofertante concorrente não poderá fazê-lo. O objetivo
da lei ao permitir a melhoria da oferta foi o de colocar em pé de igualdade, na
competição, o primeiro ofertante e o concorrente, cada um formulando sua proposta
final com o conhecimento da proposta adversária." 84

Além disso, a mesma instrução da CVM traz uma insegurança enorme para o ofertante, já que permite que haja interferências durante o leilão, o que não deixa de ser uma forma de burlar a exigência de realização da oferta pública, com todas as suas formalidades previstas em lei. O inciso II, $\S 2^{\circ}$ do artigo 12 dessa instrução disciplina que o procedimento do leilão deverá assegurar a possibilidade de "interferências compradoras, as quais poderão

\footnotetext{
${ }^{83}$ Ibid, p. 186.

${ }^{84}$ LAMY FILHO, Alfredo e PEDREIRA, José Luiz Bulhões, et al. Op. Cit. p 2042.
} 
abranger lote de ações inferior ao objeto da OPA”. Isso significa uma forma de não observar as exigências da oferta pública concorrente. Basta que um terceiro interessado faça uma intervenção no leilão através de uma ordem de compra que fique abaixo da quantidade máxima que ofertante inicial realizou. Ou seja, na hipótese do primeiro ofertante ter se proposto a adquirir 100\% das ações da companhia alvo, caso o terceiro interveniente faça uma ordem de compra por um preço $5 \%$ superior $^{85}$ ao ofertante inicial e para uma quantidade minimamente inferior, este interveniente pode acabar adquirindo o controle da companhia sem ter realizado a oferta pública, sem ter cumprido todas as exigências legais para realização da mesma. A única vedação ao interveniente é que ele não poderá adquirir as ações através da permuta, pois essa depende de registro na CVM, conforme exige o $\$ 1^{086}$ do artigo $2^{o}$ da Instrução CVM n ${ }^{\circ}$ 361.

Entendemos que a CVM deveria estabelecer uma limitação a esse tipo de intervenção de terceiros, principalmente no que tange à quantidade de ações. Sem dúvida, o mais razoável seria proibir qualquer ordem de compra durante o leilão por parte de terceiros ou pelos próprios acionistas da companhia alvo. Caso qualquer desses tenha por interesse adquirir ações da companhia, que o façam através de uma oferta concorrente. $\mathrm{O}$ ideal seria obrigar qualquer interessado em adquirir o controle de uma companhia aberta, com razoável diluição acionária ${ }^{87}$, a realizar uma oferta pública de aquisição de ações nos moldes do artigo 257 e seguintes.

\footnotetext{
${ }^{85}$ Essa exigência apenas se aplica ao interveniente caso o primeiro ofertante tenha se obrigado a realizar o pagamento das ações à vista, conforme dispõe o $\S 5^{\circ}$ do artigo 12 da Instrução CVM n ${ }^{\circ} 361$. 86 " $\$ 1^{\mathrm{O}}$ Somente estarão sujeitas a registro perante a CVM as modalidades de OPA referidas nos incisos I a III do caput, aquelas de que tratam os incisos IV e V, quando envolverem permuta por valores mobiliários, e as de que tratam o inciso VI, quando concorrerem com OPA sujeita a registro perante a CVM.”

${ }^{87}$ Neste caso, faz-se referência à aquisição originária e não a uma aquisição decorrente de alienação de controle por parte de um controlador a terceiro.
} 
Uma solução para que o ofertante não corra esse risco seria através da escolha de um procedimento especial diferente do leilão, desde que o ofertante não seja o acionista controlador ou pessoa vinculada a ele, conforme dispõe o $\S 6^{\circ}$ do artigo 12 da Instrução CVM n ${ }^{\circ} 361$. Esse ofertante deverá requisitar autorização da CVM para utilizar um procedimento alternativo ao leilão regulado no artigo 12 da referida instrução. Nota-se que essa solução não se aplica no caso da oferta pública de aquisição de controle referida no $\S 3^{\circ}$ do artigo 257 da LSA.

Em consonância com nosso entendimento, a CVM publicou o Edital de Audiência Pública nº 02/10, para alterar a Instrução n ${ }^{0}$ 361, no qual, dentre inúmeras alterações trazidas, está a proibição de interferências, conforme indicado em: "A alteração substancial ocorre no artigo 12 , $\S 2^{088}$, em que se veda as interferências...”. Sendo assim, a oferta pública será mais segura para o ofertante e até para o próprio mercado, evitando que especuladores intervenham especificamente com o intuito de inflacionar o preço das ações objeto da oferta. Outra modificação relevante está no prazo para o terceiro interessado lançar a sua oferta concorrente, anteriormente a Instrução nº 361 não limitava o surgimento de uma oferta concorrente, que poderia ocorrer até mesmo durante o leilão. Com a nova regra que será implementada pela CVM, o ofertante concorrente deverá lançar a sua oferta até 5 dias antes da data prevista para o procedimento especial.

Passar-se-á, agora, a analisar as novas alterações que poderão ser introduzidas pela nova Instrução que alterará a Instrução CVM nº 361.

\footnotetext{
88 “§2 $2^{\circ}$ No procedimento especial, são vedadas interferências compradoras, bem como a elevação de preço pelo ofertante, ressalvada a hipótese de leilão, conforme prevista no art. 13-A, inciso II.”
} 


\section{Comentários à minuta de alteração da Instrução CVM n³61.}

A CVM publicou o edital de audiência pública $n^{\circ}$ 02/10 com a intenção de receber sugestões e comentários à nova minuta que altera a Instrução CVM $\mathrm{n}^{0}$ 361. Essa minuta, caso aprovada trará grandes mudanças, a nosso ver positivas, para a oferta pública de ações e, especialmente para a oferta de aquisição de controle. Essa minuta, conforme afirmado na própria introdução do edital, foi inspirada principalmente na Diretiva Européia 2004/25/CE, de 21 de abril de 2004, bem como no Takeover Code inglês. Passaremos agora a tratar das alterações dos pontos mais relevantes para a oferta pública de aquisição de controle.

\subsection{Divulgação da oferta ao mercado: seus efeitos, sigilo e anúncio.}

Em relação às regras de divulgação, observamos alterações significativas para o anúncio da oferta e do sigilo. A Instrução CVM nº 361 trazia poucas regras sobre divulgação de informações ao mercado. Agora, existe um procedimento específico de anúncios que o ofertante deverá observar. Antes mesmo de anunciar a oferta pública de aquisição aos acionistas destinatários da oferta, o possível ofertante deverá informar a sua intenção de realizar a oferta pública à própria companhia alvo, bem como certificar-se de que possui condições financeiras de implementá-la. Isso significa que a partir do momento em que o ofertante encontra-se com estudos e análises satisfatórias que possibilitem o anúncio da oferta, incluindo-se a contratação ou negociações avançadas com uma instituição financeira intermediária que garantirá a oferta, ele deverá comunicar à empresa alvo as suas intenções. 
Na fase anterior ao anúncio, o possível ofertante deverá guardar sigilo sobre os estudos e análises da possível oferta, devendo garantir que seus empregados, assessores e terceiros envolvidos também o façam. Na hipótese de uma oscilação atípica das ações da companhia alvo ou comprovado vazamento de informações, o possível ofertante deverá imediatamente anunciar ao mercado, nos termos do artigo 4-B da minuta, a sua posição firme que irá realizar a oferta ou está realizando estudos para realização da oferta. Essas futuras regras sobre sigilo se assemelham bastante às regras presentes no RULE 1 da Section D do Takeover Code inglês, conforme indicado a título de comparação nas notas de rodapé $n^{0} 77$ e 79.

\subsubsection{Anúncio.}

De acordo com a Instrução CVM no 361, o edital deve conter uma série de informações sobre o ofertante, as condições da oferta, o preço, a instituição intermediária e uma série de outras informações exigidas no Anexo II da mesma instrução. A minuta de alteração da Instrução n 361 traz informações adicionais que o ofertante deverá apresentar ao mercado no anúncio, ou seja, antes mesmo da publicação do edital. Conforme o caput do artigo 4-B da minuta, o anúncio deverá incluir a declaração firme de que o ofertante pretende realizar a oferta e deverá conter uma série de informações previstas no novo Anexo 2. A título de exemplo, o anúncio já deverá prever, dentre outras informações, o preço, quantidade de ações, os principais termos da oferta e informações sobre os valores mobiliários detidos pelo ofertante ou suas partes relacionadas na companhia alvo anteriormente ao anúncio.

Conforme os incisos do artigo citado acima, o anúncio deverá ser endereçado ao diretor de relações com investidores da companhia alvo para 
que esse divulgue imediatamente ao mercado. Esse anúncio deverá, ainda, ser publicado pelo ofertante em jornais de grande circulação.

Com a introdução desse mecanismo de anúncio, a CVM pretende municiar os investidores com informações relevantes durante todo o período que se estende desde a primeira divulgação ao mercado, ainda que preliminar, até a data do procedimento especial. ${ }^{89}$ A preocupação com a regulamentação da fase sigilosa também é de suma importância, pois traz os procedimentos que o possível ofertante deverá tomar no caso de vazamento, dando assim, mais segurança e proteção aos investidores e acionistas das companhias envolvidas.

Caso após o anúncio o ofertante decida não realizar a oferta, estará proibido de realizar uma nova oferta pública que tenha por objeto as mesmas ações durante os próximos 6 meses, bem como adquirir no mercado uma quantidade superior a $10 \%$ de ações da mesma classe ou espécie de emissão dessa companhia.

\subsection{Regras e restrições à negociação dos valores mobiliários de emissão da companhia alvo durante o período da oferta.}

A partir do anúncio passa a vigorar a regulação quanto a negociação dos valores mobiliários da companhia alvo. A nova minuta proíbe, em seu artigo $15^{90}$, que o ofertante, ou pessoas a ele vinculadas, aliene ações da mesma classe é espécie das ações objeto da oferta. Esse mesmo artigo veda ainda que

\footnotetext{
${ }^{89}$ Artigo $3^{\circ}$, inciso VII da minuta de alteração de Instrução CVM nº361, publicada em 25 de março de 2010. "VII - período da OPA: período compreendido entre: (a) o primeiro anúncio da OPA ao mercado, ainda que preliminar; e (b) a data de realização do procedimento especial ou da revogação da OPA";

${ }^{90}$ Art. 15 da minuta de alteração de Instrução CVM n³361, publicada em 25 de março de 2010: “Art.15. Durante o período da OPA, o ofertante e pessoas vinculadas não poderão alienar, direta ou indiretamente, ações da mesma espécie e classe das ações objeto da OPA. I -Parágrafo único. Durante
} 
sejam adquiridas ações da companhia objeto no caso de uma oferta pública de aquisição parcial, ou seja, aquela que não tem por objeto a aquisição de $100 \%$ das ações de emissão da companhia alvo. Estabelece, ainda, que caso o ofertante adquira ações durante o período da oferta pública, mas fora do procedimento especial, ele não possa adquirir por um preço que seja superior ao preço da oferta. Caso isso ocorra, ele deverá aditar o edital indicando o novo preço da oferta. Esse dispositivo supre o silêncio da CVM em relação ao artigo 263 da LSA, o qual delega à CVM a expedição de normas que disciplinem a negociação das ações objeto da oferta durante o prazo da oferta pública de aquisição de controle.

Esta proibição também está presente na legislação inglesa sobre Takeovers, conforme ensinam Luiza Rangel e Isabel Bocater ${ }^{91}$ :

“- em ofertas parciais, as partes devem abster-se de comprar as ações da companhia visada, no mercado, durante o período da oferta, bem como, salvo consentimento do 'Pane', durante os doze meses seguintes ao término da oferta, se esta for bem sucedida.”

Além dessas restrições, a CVM passará a exigir de qualquer titular de ações, ou derivativos referenciados em ações, que correspondam a 2,5\% ou mais das ações da mesma espécie ou classe da companhia objeto, que disponibilize uma série de informações sobre os negócios que venham a fazer e que tenham por objeto os valores mobiliários da companhia objeto durante o período da oferta pública, nos termos do artigo 31-B da minuta que altera a Instrução 361.

o período da OPA, o ofertante e pessoas vinculadas somente poderão adquirir ações da mesma espécie e classe das ações objeto da OPA se a OPA não for parcial.”

${ }^{91}$ MORARES, Luiza Rangel de; BOCATER, Maria Isabel do P. Op. Cit. Rio de Janeiro: Legis Bancos, 1980. p 239. 


\subsection{Manifestação do Conselho de Administração da companhia alvo sobre a oferta.}

Uma das principais novidades trazidas pela minuta de instrução que altera a 361 é a exigência de manifestação pelo Conselho de Administração da companhia alvo indicando se é ou não favorável à aceitação da oferta pelos acionistas. A CVM considera tal manifestação muito importante para a decisão dos acionistas. ${ }^{92}$ De fato, essa manifestação é de suma importância para qualificar a oferta com amigável ou hostil, ou seja, caso a oferta seja rejeitada pelo Conselho de Administração da companhia alvo, a oferta passará a ser considerada indesejável e, por conseguinte, hostil.

Essa manifestação foi inspirada tanto na Diretiva Européia 2004/25/CE ${ }^{93}$, de 21 de abril de 2004, quanto no Takeover Code ${ }^{94}$ inglês, apesar de não ter o nível de detalhamento contido no Code inglês que, por exemplo, exige que o Board of Directors da empresa alvo se manifeste sobre os planos do ofertante em relação aos empregados da empresa alvo. Essa questão também deveria ter sido abraçada pela minuta por ser de grande

\footnotetext{
${ }^{92}$ Item 3, p. 3 do Edital de Audiência Pública no02/10, publicado em 25 de março de 2010. Disponível no site www.cvm.gov.br. Acesso em: 31 de outubro de 2010.

${ }^{93}$ Artigo $9^{\circ}, n^{\circ} 5$ Diretiva Européia 2004/25/CE ${ }^{93}$, de 21 de abril de 2004: 5 . O órgão de administração da sociedade visada deve elaborar e tornar público um documento de que conste o seu parecer fundamentado sobre a oferta, nomeadamente quanto às repercussões da aplicação da oferta sobre os interesses da sociedade no seu conjunto, incluindo o emprego, e quanto aos planos estratégicos do oferente para a sociedade visada e as suas eventuais repercussões a nível do emprego e dos locais em que a sociedade exerça actividade enunciados no documento de oferta, em conformidade com a alínea i) do n.o 3 do artigo 6.o O órgão de administração da sociedade visada deve apresentar simultaneamente este parecer aos representantes dos trabalhadores da sociedade ou, na sua falta, aos próprios trabalhadores. Se o órgão de administração da sociedade visada receber em tempo oportuno um parecer distinto dos representantes dos trabalhadores quanto às repercussões a nível do emprego, este será apenso ao referido documento. Disponível no site: http://eurlex.europa.eu/LexUriServ/LexUriServ.do?uri=OJ:L:2004:142:0012:0012:PT:PDF. Acesso realizado em 02 de novembro de 2010.

${ }^{94}$ Neste sentido ver o RULE 25.1 do Takeover Code ingles: "VIEWS OF THE BOARD ON THE OFFER, INCLUDING THE OFFEROR'S PLANS FOR THE COMPANY AND ITS EMPLOYEES (a) The board of the offeree company must send its opinion on the offer (including any alternative offers) to the offeree company s shareholders and persons with information rights. It must, at the same time,
} 
importância, uma vez que poderão ser implantadas sinergias entre as empresas após a aquisição, o que pode resultar em cortes de empregos, além de questões que envolvem previdência, benefícios e demais políticas trabalhistas.

A minuta traz uma série de regras, em seu artigo 31-A, para a manifestação do Conselho, que deverá ser realizada em até 10 dias antes da data prevista para o procedimento especial. O conselho deverá opinar, necessariamente, sobre o preço da oferta e suas condições, bem como deverá divulgar quaisquer estudos ou laudos de avaliação que tenha realizado ou contratado para análise da oferta. Deverá, ainda, fornecer informações sobre os valores mobiliários objeto da oferta que por ventura sejam detidos ou tomados por empréstimo pela própria companhia, por seus administradores ou pessoas vinculadas a companhia e outras informações relevantes indicadas no referido artigo.

Para fins de exemplo, essa manifestação do Conselho de Administração da companhia alvo, que passará a ser exigida pelas novas regras da CVM, se assemelha bastante à Directors' Circular $^{95}$ da Potash Corporation of Saskatchewan Inc. que acabou por recomendar, os seus acionistas, a rejeição à oferta realizada pela BHP Billiton Plc para aquisição do controle da Potash Corp.

\subsection{Aquisição das ações remanescentes e aprovação da oferta parcial por mais da metade dos acionistas.}

make known to its shareholders the substance of the advice given to it by the independent advisers appointed pursuant to Rule 3.1".

95 PotashCorp Directors' Circular Resolution, August 23, 2010. p.1. Disponível em: http://www.potashcorp.com/media/POT_PotashCorp_Directors_Circular.pdf. Acesso realizado em 25 de setembro de 2010. 
Outra grande novidade trazida pela minuta é a opção dos acionistas remanescentes venderem suas ações pelo prazo de 3 meses contados a partir da realização do procedimento especial. Conforme a explicação da CVM presente no Edital de Audiência Pública, essa opção de venda é uma forma de evitar que o acionista se veja compelido a vender suas ações, no caso de temer que o sucesso da oferta possa afetar negativamente o valor das ações que não sejam adquiridas na oferta pública.

"Diante de uma oferta pública voluntária para aquisição de controle de uma sociedade de capital disperso, o acionista pode se ver impelido a aceitar a oferta por estimar que a presença de um acionista controlador reduzirá o valor das ações que permanecerem em circulação. Essa expectativa pode ser creditada por várias razões. A hipótese que mais bem ilustra é a perspectiva de incorporação da companhia pelo seu novo controlador, a um preço inferior ao da OPA."96

Entretanto essa regra reduziria a possibilidade de existência de ofertas públicas parciais, ou seja, aquelas em que o ofertante não se compromete a adquirir $100 \%$ das ações de emissão da companhia alvo. Para evitar essa situação, a CVM buscou inspiração na legislação inglesa. ${ }^{97}$

A solução encontrada foi separar o momento da aprovação da oferta pelos acionistas da companhia alvo do momento da aceitação da oferta. Dessa forma, os acionistas deverão reunir-se em Assembleia Geral para deliberar se aprovam ou não a oferta em até cinco dias da data do procedimento especial. Caso a oferta seja aprovada por mais da metade dos acionistas, esta não está sujeita no futuro à opção de venda da participação dos acionistas remanescentes. A aceitação pelos acionistas apenas será manifestada durante o procedimento especial.

\footnotetext{
${ }^{96}$ Item 5, p. 5 do Edital de Audiência Pública n ${ }^{\circ}$ 02/10, publicado pela CVM em 25 de março de 2010. Disponível no site: www.cvm.gov.br. Acesso em: 02 de novembro de 2010.

${ }^{97}$ Ver nota de rodapé $n^{\circ} 31$.
} 
Esse mecanismo é extremamente favorável ao investidor, especialmente no caso de uma oferta que não tenha um limite máximo de ações que o ofertante se propõe a adquirir. Mesmo que o acionista da companhia alvo tome a decisão errada de não alienar suas ações durante o período da oferta, terá a faculdade de vender as suas ações pelo preço atualizado na forma estabelecida no edital até 3 meses após a data do procedimento especial.

Acreditamos que o mecanismo criado para a oferta parcial é de grande importância, pois dá mais seguranças aos acionistas e ao mesmo tempo não obriga o ofertante a adquirir uma quantidade de ações que nunca havia se comprometido a adquirir. Essa aprovação poderá constar no edital como uma das condições para prosseguimento da oferta pública e a ocorrência do procedimento especial.

\subsection{Procedimento especial.}

A CVM pretende substituir o leilão pelo procedimento especial que inclui algumas novidades que aperfeiçoam a oferta pública de aquisição de controle, entretanto ainda cabe ao ofertante decidir pela adoção ou não do procedimento especial, podendo, ainda, no caso de oferta concorrente, escolher a forma de leilão.

O procedimento especial observa os mesmo prazos que eram aplicados ao leilão, ou seja, de 30 a 45 dias contados da publicação do edital. Os grandes benefícios trazidos pela mudança estão na proibição de interferentes compradores e do aumento de preços durante o procedimento especial o que trará mais transparência e segurança aos acionistas da empresa alvo e aos ofertantes, evitando, assim, que haja especulação sobre o valor das ações. 
A possibilidade de escolha do leilão no caso de oferta concorrente, conforme o item 6 do Edital de Audiência Pública foi inspirada no Takeover Code, e deverá ser analisada pela CVM. O leilão surge como solução para as hipóteses em que a disputa pelo controle de uma companhia se prolonga por um tempo excessivo. Nesse caso, são permitidos aumentos de preços por parte dos concorrentes. 


\section{Conclusão.}

Analisado o instituto da oferta pública de aquisição de controle no Brasil e apresentadas as principais mudanças que estão por vir com a alteração da Instrução CVM n ${ }^{0}$ 361, podemos, agora, prosseguir aos comentários finais sob uma abordagem crítica.

Apesar das importantes mudanças que a CVM pretende realizar após a conclusão da nova instrução que altera a Instrução CVM nº 361, a CVM não procurou realizar mudanças mais significativas na oferta pública de aquisição de controle. Acreditamos que a CVM não pretendeu entrar em um nível de detalhamento de procedimentos tão avançado como se pode observar nas legislações inglesas e americanas. Provavelmente, a CVM não quis burocratizar de sobremaneira o procedimento da oferta pública de aquisição do controle para não desencorajar a utilização deste tipo de oferta no Brasil.

Entretanto, a CVM poderia ter ido um pouco além e ter aproveitado mais a influência da Diretiva Européia 2004/25/CE, de 21 de abril de 2004, que não é extremamente densa como o Takeover Code inglês ou a regulamentação da SEC de 1934. Essa Diretiva, que aborda apenas princípios e as regras gerais que os países membros da União Européia devem observar, apresenta uma quantidade de dispositivos importantes que talvez a CVM não tenha entendido que fossem relevantes para serem aplicados no Brasil.

Nessa Diretiva, temos, por exemplo, a sugestão aos Estados membros de imporem algumas limitações aos poderes dos órgãos de administração da companhia alvo em relação a certas operações de caráter excepcional, desde 
que não afetem indevidamente o curso normal das atividades societárias da companhia, conforme estabelece o Considerando $\mathrm{n}^{\circ} 16^{98}$

Podemos citar como exemplo, as restrições previstas no Takeover Code inglês, conforme nos ensinam Luiza Rangel e Isabel Bocater ${ }^{99}$ :

"a administração da companhia visada, quando no curso de uma oferta, ou sabendo de sua iminência, não pode, exceto se houver prévio contrato, sem a autorização da Assembleia Geral, emitir ações no limite do capital autorizado, ou emitir ou conceder opções relativas a ações ainda não emitidas, ou criar quaisquer títulos conversíveis em ações, ou que dêem direito a subscrição; isto também se aplica a qualquer ato ou acordo para disposição ou aquisição de ativos em montante relevante, e a contratos que excedam a gestão ordinária. Se ocorrerem circunstâncias especiais, o 'Panel' deve ser consultado e seu consentimento obtido.”

“a administração da companhia visada deve agir de modo a assegurar o pronto registro de transferência das ações envolvidas em uma oferta, de modo a que os acionistas possam, livremente, exercer seus direitos, inclusive de voto; disposições estatutárias fixando um período de carência, após o registro de transferência, para o exercício do direito de voto, são inteiramente indesejáveis.”

Podemos observar que estas proibições reduzem a capacidade de os administradores utilizarem seus poderes para inviabilizar a concretização da oferta pública de aquisição formulada por um terceiro interessado. Desta forma, eles deverão administrar a companhia de acordo com o curso ordinário dos negócios, ou seja, não poderão celebrar contratos que impactem expressivamente no orçamento da empresa, tornando-a desinteressante para qualquer ofertante.

Existem diversas formas de defesa que os administradores podem utilizar como, por exemplo: as chamadas as "embedded defences", que são contratos celebrados com fornecedores ou parceiros estratégicos nos quais

\footnotetext{
98 “16 - Para evitar operações que possam comprometer o êxito de uma oferta, deverão ser limitados os poderes do órgão de administração de uma sociedade visada em relação a certas operações de carácter excepcional, sem impedir indevidamente a sociedade visada de prosseguir o curso normal das suas actividades."

${ }^{99}$ MORARES, Luiza Rangel de; BOCATER, Maria Isabel do P. OP. Cit. p 241.
} 
existe uma multa de grande valor no caso de ocorrência de alteração do controle da empresa; e as denominadas "scorched earth" que consiste na alienação de um ativo de grande valor para a companhia alvo ou ainda um ativo que desperte um grande interesse pelo o ofertante e que, caso seja alienado, a oferta de aquisição da companhia alvo perde o seu propósito. ${ }^{100}$

Existem, além desses mecanismos citados, outras dezenas de táticas que os administradores podem utilizar para evitar que a companhia seja alvo de uma oferta. Desta forma, seria de extrema importância que a nova instrução apresentasse algumas regras para que os administradores não pratiquem nenhum ato fora do curso normal da administração. Hodiernamente, os ofertantes especificam no edital de oferta que a companhia deverá seguir o curso ordinário de seus negócios como condição para a concretização da aquisição. Consideramos que este entendimento deveria estar previsto na própria norma da CVM para dar mais segurança à oferta pública de aquisição de controle.

Outra falta importante observada na minuta que altera a Instrução CVM $n^{\circ}$ 361, já foi especificada no item 4.2 deste estudo, que é a obrigatoriedade dos ofertantes e do conselho de administração da companhia alvo se manifestarem sobre as repercussões que a oferta e a aquisição terão nos empregados da companhia alvo. Neste ponto, a nova minuta se importou muito mais na proteção do investidor - o que é louvável, mas esqueceu de se manifestar em relação à proteção dos empregados da sociedade. A insatisfação dos trabalhadores com a oferta e a aquisição pode causar um impacto direto nos resultados da companhia e causar prejuízo enorme aos seus investidores caso, por exemplo, os empregados decidam entrar em greve e paralisar as operações

\footnotetext{
${ }^{100}$ FERRARINI, Guido e MILLER, Geoffrey P., OP. Cit. Disponível na internet no sítio: http://organizations.lawschool.cornell.edu/ilj/issues/42.3/CIN301.pdf. Acesso realizado em 25 de
} 
da companhia. Sendo assim, considero de grande importância que o ofertante já disponibilize informações possam impactar diretamente nos empregados da companhia alvo, bem como especificar as políticas de trabalhistas que pretendem implementar caso adquiram o controle.

Neste sentido, a referida Diretiva Européia foi além e, no seu considerando $\mathrm{n}^{\mathrm{o}}$ 23, dispôs da seguinte forma: “Convém, contudo, prever a possibilidade de os trabalhadores das sociedades interessadas, ou seus respectivos representantes, emitirem o seu parecer sobre as repercussões possíveis da oferta em matéria de emprego.”

Estes pontos acima apresentados são exemplos de questões que deveriam ter sido abordadas para que a CVM pudesse aperfeiçoar as alterações que pretende fazer na Instrução CVM no 361. Certamente existem outras questões relevantes que não foram tratadas na minuta que altera a referida Instrução e que também não foram apontadas no presente trabalho. Um estudo mais detalhado das ofertas públicas de aquisição de controle nos países em que ela é largamente difundida poderia apontar outras questões que a CVM devesse regular.

Entretanto devemos considerar que as alterações apresentadas são positivas e que a regulamentação da oferta pública de aquisição de controle no Brasil passou a ter uma regulamentação mais compatível com as regulamentações estrangeiras mais desenvolvidas. Conforme citado anteriormente, as principais novidades surgiram: nas divulgações de informações; na obrigatoriedade manifestação do conselho de administração da companhia alvo; nas restrições às negociações durante o prazo da oferta; e a criação do procedimento especial que veda elevações de preços e 
interferências. Estas modificações acabaram com algumas incompatibilidades que existem entre a Instrução CVM n ${ }^{0} 361$ e a LSA.

Por fim, estas alterações tornarão o processo de oferta pública de aquisição de controle, mais interessante para o ofertante e mais seguro para o mercado em geral. Isso não significa que o este forma de oferta será mais utilizada no futuro, pois a sua aplicação continuará restrita enquanto durar a característica de predominância do controle majoritário dentre as companhias abertas brasileiras.

O presente trabalho buscou apresentar o instituto da oferta pública de aquisição de controle em vigor no Brasil e antecipar algumas mudanças que estão por vir e foram disponibilizadas ao público. Até o presente momento, a CVM não publicou a alteração definitiva à Instrução CVM nº 361, portanto algumas considerações que foram tomadas neste trabalho não poderão verificar-se após a publicação da nova instrução. 


\section{Referências Bibliográficas}

CARVALHOSA, Modesto de Souza Barros. Oferta pública de aquisição de Ações, Rio de Janeiro, IBMEC, 1979, 211p.

COMPARATO, Fabio Konder e SALOMÃO FILHO, Calixto. O poder de controle na sociedade anônima. Ed. Forense, Rio de Janeiro, 2008. p. 51- 88 e $237-260$

Directiva 2004/25/CE do Parlamento Europeu e do Conselho de 21 de abril de 2004. Disponível no site: http://eur-lex.europa.eu/LexUriServ/LexUriServ.do? uri=OJ:L:2004:142:0012:0012:PT:PDF. Acesso realizado em 02 de novembro de 2010.

EIZIRIK, Nelson. et. al., Mercado de Capitais Regime Jurídico. Rio de Janeiro. Renovar. 2008.

FERRARINI, Guido e MILLER, Geoffrey P., A simply Theory of Takeover Regulation in the United States and Europe. Cornell International Law Journal. Vol. 42. 2010. Disponível na internet no sítio: http://organizations.lawschool. cornell.edu/ilj/issues/42.3/CIN301.pdf. Acesso realizado em 25 de setembro de 2010.

LAMY FILHO, Alfredo e PEDREIRA, José Luiz Bulhões, et al. Direito das Companhias, 1a ed., 2009, p 2031 -2044.

MORARES, Luiza Rangel de; BOCATER, Maria Isabel do P. Oferta Pública de Aquisição do Controle (Art. 257 e seguintes da Lei $n^{o}$ 6.404/76) Estudo 
Jurídico Básico, Gerência de Legislação e Pesquisa, Superintendência Jurídica. Rio de Janeiro: Legis Bancos, 1980. p 85 - 287.

Securities Exchange Act 1934. Disponível na internet: www.sec.gov Acesso: 30 de outubro de 2010.

The City Code On Takeover and Mergers, $9^{\text {th }}$ edition, March 30, 2009. Disponível na internet: http://www.thetakeoverpanel.org.uk/wpcontent/uploads/2008/11/code.pdf. Acesso em 19 de outubro de 2010.

White Paper on Corporate Governance in Latin America - Organization for Economic Co-operation and Development - OECD, 2003. Disponível na internet: www.ocde.com. Acesso: 25 de setembro de 2010. 